\title{
Replication Stress, DNA Damage, Inflammatory Cytokines and Innate Immune Response
}

\author{
Sandrine Ragu ${ }^{\dagger}$, Gabriel Matos-Rodrigues ${ }^{\dagger}$ (i) and Bernard S. Lopez *(i) \\ Institut Cochin, INSERM U1016, UMR 8104 CNRS, Université de Paris, Equipe Labellisée Ligue Contre le \\ Cancer, 24 rue du Faubourg St Jacques, 75014 Paris, France; sandrine.ragu@inserm.fr (S.R.); \\ gabriel-eduardo.de-matos-rodrigues@inserm.fr (G.M.-R.) \\ * Correspondence: bernard.lopez@inserm.fr \\ + Equal contributions.
}

Received: 9 March 2020; Accepted: 6 April 2020; Published: 9 April 2020

\begin{abstract}
Complete and accurate DNA replication is essential to genome stability maintenance during cellular division. However, cells are routinely challenged by endogenous as well as exogenous agents that threaten DNA stability. DNA breaks and the activation of the DNA damage response (DDR) arising from endogenous replication stress have been observed at pre- or early stages of oncogenesis and senescence. Proper detection and signalling of DNA damage are essential for the autonomous cellular response in which the DDR regulates cell cycle progression and controls the repair machinery. In addition to this autonomous cellular response, replicative stress changes the cellular microenvironment, activating the innate immune response that enables the organism to protect itself against the proliferation of damaged cells. Thereby, the recent descriptions of the mechanisms of the pro-inflammatory response activation after replication stress, DNA damage and DDR defects constitute important conceptual novelties. Here, we review the links of replication, DNA damage and DDR defects to innate immunity activation by pro-inflammatory paracrine effects, highlighting the implications for human syndromes and immunotherapies.
\end{abstract}

Keywords: DNA damage response; replicative stress; DNA repair; innate immunity; inflammation; cGAS-STING

\section{Introduction}

The maintenance of genome stability is essential to the accurate transmission of genetic information. Indeed, genome instability is a hallmark of cancer cells [1]. However, the genome is routinely insulted by endogenous as well as exogenous attacks that can generate genetic instability, which ultimately may promote carcinogenesis and/or ageing. Replication and oxidative stresses are major sources of endogenous genotoxic assaults that jeopardize genome stability. Of note, these two endogenous stresses are closely linked, as oxidative stress generates replication stress [2,3].

During DNA synthesis, the replication machinery must overcome numerous obstacles, including consequences of oxidative stress, tightly bound DNA-protein complexes, non-B form DNA structures (such as R loop) and lesions that interfere with fork progression [4]. These events can ultimately lead to replication stress by replication fork stalling, collapse or breakage $[5,6]$. Several mechanisms can be at the origin of replication stress, such as oncogene activation, nucleotide pool imbalance and conflict between replication and transcription [5,6]. These different mechanisms can be connected. Transcription complexes are one prominent endogenous challenge to replication forks. Transcription-replication conflicts (TRCs) can induce DNA replication-fork stalling, DNA recombination, DNA breaks and mutations [7-10]. Therefore, TRCs pose a potential threat to genome stability [11]. One transcription-associated replication fork barrier is the R-loop, an RNA-DNA hybrid 
formed when nascent transcripts re-anneal to their template DNA, displacing the non-template strand as single-stranded DNA (ssDNA) [12]. Elevated R-loop levels cause DNA damage and genome instability. The loss of RNA processing and regulatory factors increases R-loop levels, causing R-loop dependent DNA damage in eukaryotic cells [13-16].

DNA breaks and activation of the DNA damage response (DDR), arising from endogenous replication stress, have been observed at early or precancerous stages, and adaptation to replication stress plays an important role in tumour development [17-20]. The DDR protects genome stability through the precise coordination of a network of pathways, ensuring faithful transmission of genetic material, including DNA replication, repair and recombination, cell cycle checkpoint and chromosome segregation. Ultimately, these autonomous cell responses induce senescence or cell death [21-25]. All these processes prevent the proliferation of cells bearing DNA damage and/or genetic rearrangements. In agreement, syndromes caused by mutations in DDR and/or DNA repair factors are often associated with high genetic instability, cancer predisposition and premature ageing [24,26-28]. In addition to these cell-autonomous responses, protective process(es) also act at the organism level. Such mechanism(s) involve the modification of the cellular microenvironment and ultimately the activation of innate immunity.

The inflammatory response is a universal cell-intrinsic response to infections or tissue damage. Inflammation, which is triggered when innate immune cells detect infection, for example, eliminates the initial cause of cell injury, clears out necrotic cells and tissues damaged from the original insult and from the inflammatory process, and initiates tissue repair [29].

To maintain homeostasis, the organisms must maintain a delicate balance in the activation of inflammatory responses. On one hand, an insufficient response results in the susceptibility to infections or tumour development; on the other hand, excessive or self-antigen responses lead to allergy or autoimmune diseases. A possible initial step in innate immune activation is the recognition by the host cell of the foreign features of infectious agents [29,30]. In this case, sensor proteins inspect extracellular and cytoplasmic spaces for the presence of pathogens through pattern recognition receptors (PRRs) and trigger immune responses upon their activation [29,31]. Additionally, the induction of innate immune responses can also occur in the absence of infection, such as when cells recognize self nucleic acids in unwanted subcellular compartments [32].

Pioneering works have shown connections between the immune response and self-DNA and the DDR. It has been demonstrated that DNA damage can trigger innate immune responses through the accumulation of nuclear DNA in the cytoplasm and micronuclei and/or the chronic DNA damage response signalling activation by itself [33-36]. In this review, we will discuss how replicative stress and DNA damage (mainly DNA double-strand breaks, DSBs) can activate innate immunity and the consequences for autoimmune diseases and immunotherapy.

\section{Cytoplasmic DNA-Mediated Inflammatory Response}

The cyclic GMP-AMP synthase (cGAS)-stimulator of interferon genes (STING), cGAS-STING, pathway plays a pivotal role in the DNA damage-induced innate immune response [34,36,37] (Figure 1). The cGAS protein is a DNA sensor that catalyses the production of cyclic guanosine monophosphate-adenosine monophosphate (c-GMP-AMP or cGAMP) as a second massager [38-41]. In vitro, biochemical approaches showed that cGAS is able to bind double strand RNA (dsRNA), ssDNA and double strand DNA (dsDNA), but that only dsDNA can drive cGAMP production [42]. Additionally, cGAS is activated in a dsDNA length-dependent manner. Human cGAS is able to bind and be activated by short dsDNA sequences ( 20 bp), but longer dsDNA (500-4000 bp) trigger a greater cGAMP production and innate immune activation [42-44]. STimulator of INterferon Genes (STING) is a dimeric endoplasmic reticulum (ER)-binding protein that is activated by cGAMP and other forms of cyclic dinucleotides produced by bacterial metabolism $[45,46]$. The production of cGAMP by cGAS leads to STING oligomerization and translocation to the Golgi apparatus where it activates its downstream targets $[47,48]$. STING can activate a transcriptional response via the activation of 
TANK-binding kinase 1 (TBK1) and both the canonical and non-canonical NF- $\mathrm{kB}$ pathways [46]. Oligomerization of STING after cGAMP binding creates a signalling platform that recruits and activates TBK1, which reciprocally phosphorylates STING [47-50]. Phosphorylated STING then binds the transcription factor Interferon Regulatory Factor 3 (IRF3), which is subsequently phosphorylated by TBK1 $[47,48,50,51]$. Once activated, IRF3 translocates to the nucleus and acts as a transcriptional activator of type I interferon (IFN) genes. Different members of the NF- $\mathrm{KB}$ pathway are TBK1 targets. For instance, it has been shown that TBK1 can activate the canonical NF- $\mathrm{kB}$ pathway through the phosphorylation of IKB and/or p65 (RelA) [51,52]. In addition, cytoplasmic DNA is able to activate the non-canonical NF- $\mathrm{kB}$ pathway in a STING-dependent and TBK1-independent manner by increasing p100 phosphorylation [53,54]. By interacting with its different partners, the cGAS-STING pathway can change the cellular transcriptional program and activate an innate immune response triggered by cytoplasmic DNA.

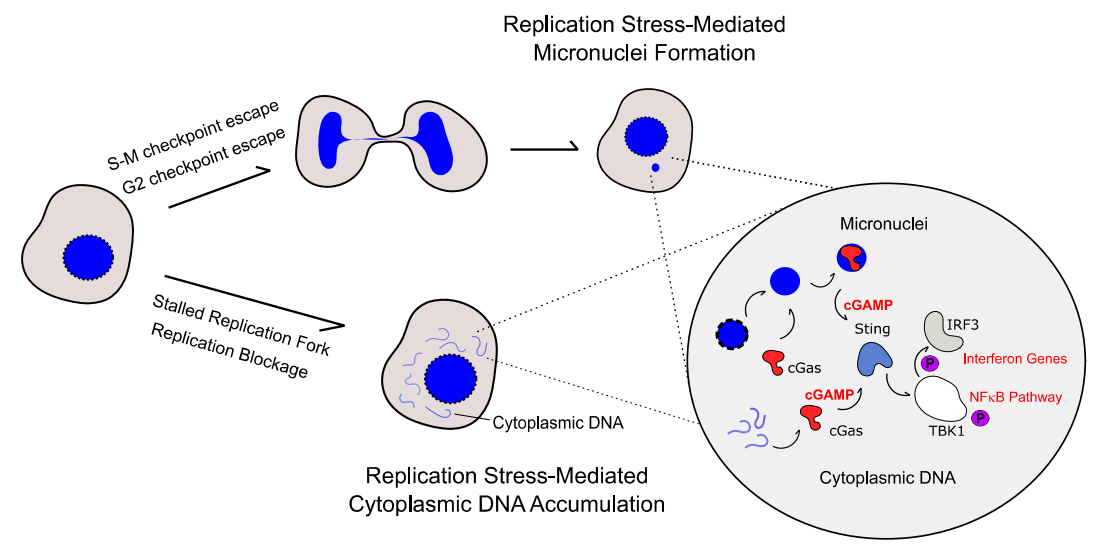

Figure 1. cGAS-STING pathway activation by replicative stress. Two different pathways can trigger cGAS-STING activation by replicative stress: (1) the formation of micronuclei and (2) the accumulation of replication fork-derived DNA in the cytoplasm. These events will trigger the activation of cGAS, which produces cGAMP, activating the STimulator of INterferon Genes (STING) protein. Once activated, STING recruits TBK1 that is then able to phosphorylate its different targets that include Interferon Regulatory Factor 3 (IRF3) and different members of the NF- $\mathrm{KB}$ signalling pathway. This culminates in an upregulation of pro-inflammatory factors.

\section{Replication Stress Induces the Production of Pro-Inflammatory Cytokines}

The accumulation of cytoplasmic ssDNA and dsDNA is also a common feature of tumours and cancer cell lines $[34,55,56]$. It has been proposed that DNA damage and replication stress elicit the activation of inflammatory responses that contribute to tumourigenesis in some contexts and to senescence/aging in others [57,58]. Indeed, cells exposed to replication stress-inducing agents or deficient in the replication stress response have enhanced production of type I IFNs and pro-inflammatory cytokines that can foster an innate immune response [59-62].

Two events have been suggested to trigger the activation of the cGAS-STING pathway by nuclear DNA accumulation in the cytoplasm after replication stress (Figure 1). First, the disruption of the replication fork integrity is a major source of cytoplasmic DNA accumulation after replication blockage $[59,63]$. The inactivation of DNA repair factors that protect and resume arrested replication forks also enhances the accumulation of nuclear DNA into the cytoplasm $[63,64]$. Importantly, the mechanisms underlying the extrusion of replicating DNA from replication blockage are still not known. As discussed above, in vitro analysis did not show cGAMP production by ssDNA stimulation of cGAS, and some studies reported only the accumulation of ssDNA (single strand DNA) but not double strand DNA (dsDNA) after replication blockage [63,65]. To reconcile these observations, one can propose that secondary structures of the ssDNA can generate the dsDNA sequences able to then activate the cGAS-STING pathway. 
Second, upon replication stress, cells containing genomes not fully replicated and/or bearing DNA damage can reach mitosis, leading to mitotic defects, including the formation of micronuclei [66-68]. Recent studies have shown that micronuclei structures derived from chromosomal missegregation serve as a platform for the DNA damage-induced immune response [69-72]. Indeed, exposure to genotoxic chemicals or inactivation of DNA repair factors that leads to replicative stress triggers micronuclei formation and cGAS-STING activation [73,74]. Evidence suggests that micronuclei envelope rupture allows the recognition of the chromatin as cytoplasmic DNA by cGAS-STING [69-71].

To prevent aberrant DNA-driven (auto)immune reactions, cells employ a battery of DNases, such as DNase I in the extracellular space, DNase II in endolysosomes or TREX1 (DNase III) in the cytoplasm, that are responsible for the immediate degradation of DNA by-products before the DNA sensing pathways are activated [75]. Different studies have shown enhanced accumulation of replication fork-derived ssDNA in the cytoplasm upon TREX1 inactivation [59,63-65,76]. It has been shown that the excess of short free ssDNA that accumulates in TREX1-deficient cells is bound by Replication Protein A (RPA) and RAD51 both in the cytosol and the nucleus [76]. By affecting the availability of proteins such as RAD51, RPA, and MRE11, the innate immune response to replication stress-associated self-DNA may become another determinant of cancer susceptibility to chemotherapy. In summary, these results show that higher eukaryotes cells have several layers of mechanisms to hinder nuclear DNA recognition in the cytoplasm after replicative stress.

\section{DDR and DNA Repair Defects}

Another piece of evidence linking DNA damage and the immune response comes from DDR/DNA repair-deficient patients and animal models. Genetic deficiencies that compromise DDR functions also induce cytokines and lead to auto-inflammatory diseases. Similar to exogenous DNA damage, inherent DNA repair defects in tumours may also increase the production of cytosolic DNA and appear to trigger the STING-dependent response [77].

Replication stress is closely related to DNA DSBs. Indeed, the prolonged arrest of replication forks generates DSBs, and, reciprocally, a replication fork reaching a nick or a gap in the copied DNA is converted in a DSB [78] (and for review [6,79]). Additionally, homologous recombination factors such as RAD51 and BRCA2 act to protect the arrested replication fork from degradation, and restarts replication (Figure 2A,B).

\subsection{DNA Damage Signalling and Processing of Double-Strand Ends}

DNA damage should first be signalled to coordinate the cell responses, including cell cycle checkpoint and DNA repair/recombination. Two main types of DNA alterations are signalled: ssDNA stretches and DSBs (Figure 3). However, some overlap can exist. Indeed, resection at DSBs generates ssDNA that can then activate the ssDNA-signalling pathways.

Replication fork blockage and stalling are examples of replicative stress events that leads to the formation of ssDNA stretches $[5,80]$. Although ssDNA accumulation is the most common origin of replicative stress, ssDNA-independent sources have been reported [5,81]. Replication Protein A (RPA) coated single strand DNA serves as a platform to the recruitment other accessory proteins (e.g., Rad9, ETAA1 and TOBP1) that enable ATRIP-ATR complex activation (Figure 3A). The ATRIP-ATR complex is the central player in the replicative stress response. Along with its downstream target Chk1, these protein kinases phosphorylate hundreds of substrates to control cell cycle arrest, DNA repair and/or cell death [5,82]. Although replicative stress does not refer to the formation of DSB, these events are closely related. The collapse of replication forks can lead to the formation of DSB by replication fork reversion or by endonuclease processing in a process that is accelerated by replicative stress response inactivation $[78,83,84]$. These DSB ends are recognized by the MRN (MRE11, RAD50 and NBS1) complex (Figure 3B). Once associated with the DSB ends, this complex activates the protein kinase Ataxia Telangiectasia-Mutated (ATM) that is a major signalling hub. ATM targets exhibit a plethora of targets and regulate many aspects of cellular metabolism. Of note, ATM regulates cell cycle 
and apoptosis through $\mathrm{CHK} 2$ and/or p53, for example, or chromatin remodelling and DNA repair by BRCA1 and/or H2AX phosphorylation [85,86].

A.

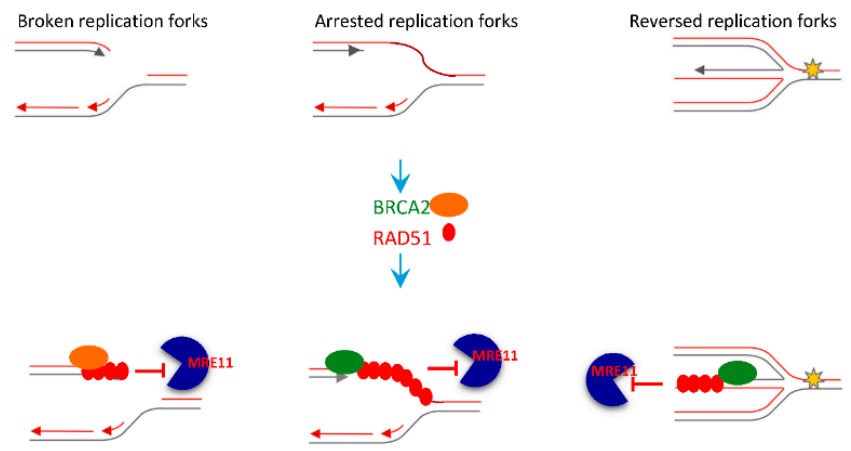

B.

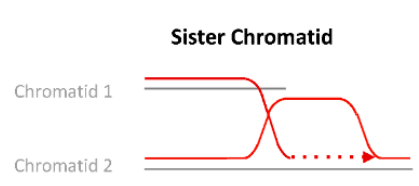

Figure 2. Replication fork protection and restart. (A). A replication fork can be broken, or arrested; when reaching an obstacle that arrested it, replication fork can also be reversed generating a so called "chicken foot" structure (right panel). Various actions may take place to protect the replication forks including: BRCA2 loading of RAD51 to protect the forks and/or BRCA2 stabilizing the RAD51 nucleofilament on the single-stranded DNA (ssDNA) regions, thereby preventing MRE11, CtIP, and EXO1-dependent resection (preventing degradation of the arrested forks). (B). The strand exchange activity of RAD51 allows then to restart arrested replication forks, using a homologous sequence as matrix, generally the sister chromatid, leading to sister chromatid exchange.

A
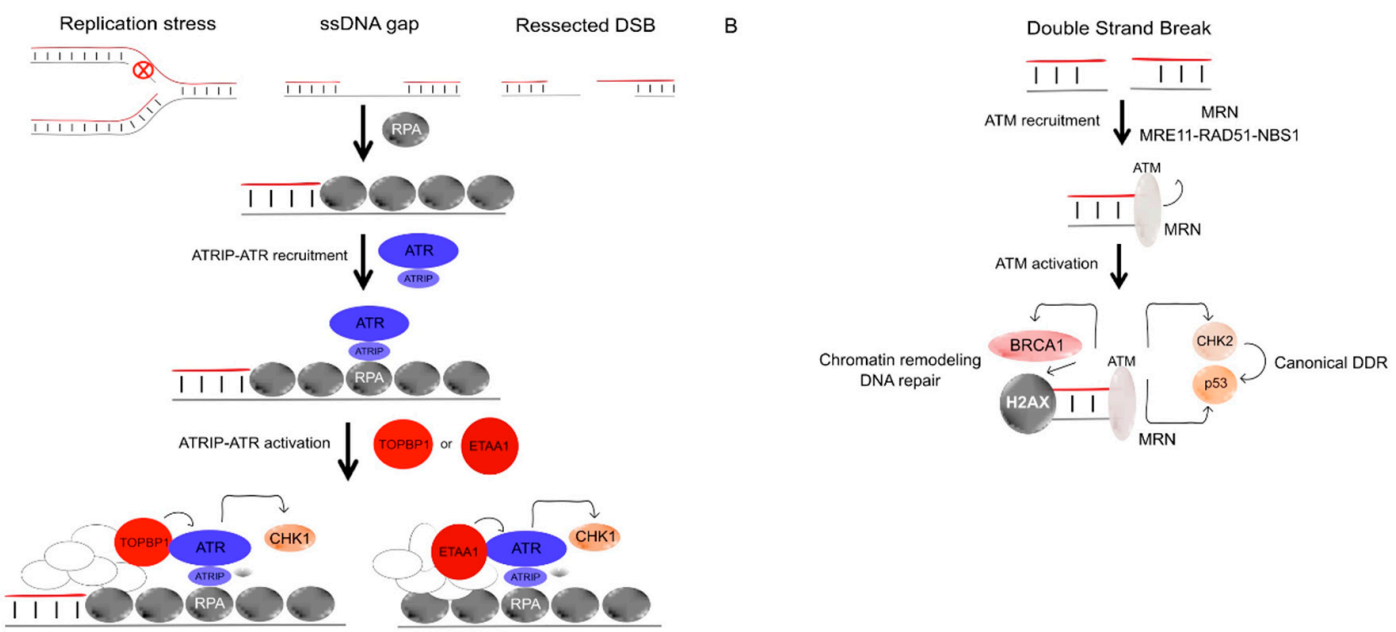

Figure 3. ATR-interacting protein-ataxia telangiectasia and Rad 3 related (ATRIP-ATR) and ataxia telangiectasia-mutated (ATM) signalling. (A). Replication stress events (e.g., replication fork stalling), ssDNA gaps or resected DSB ends lead to the formation of ssDNA stretches. Replication Protein A (RPA) binds the ssDNA stretches and serve as a platform for ATRIP-ATR recruitment. Two modes of ATRIP-ATR activation have been described: in association with accessory proteins TOPBP1 or ETAA1 bind ATR triggering its autophosphorylation. Activated ATR, then, phosphorylate its downstream targets that include the protein kinase CHK1. (B). The MRN (MRE11-RAD50-NBS1) complex recognize the DSB. ATM is recruited to the DSB site and binds the MRN complex, which leads to ATM activation. ATM then phosphorylates its downstream targets, including CHK2 and p53 during the canonical DNA damage response (DDR) and/or H2AX and BRCA1 for chromatin remodelling and DNA repair. 
Two general strategies repair DSBs (Figure 4): NHEJ (non-homologous end-joining) ligates the two double strand ends without requiring sequence homologies, while in contrast, homologous recombination (HR) relies on the use of a DNA partner sharing a homologous sequence that provides an intact copy for DSB repair. Alternative DSB repair processes also exist generally based on the use of micro-homologies (2 to $4 \mathrm{bp}$ ) at the junctions (For review see [79,87]). HR is frequently proposed to be error-free, while the canonical non-homologous end-joining (C-NHEJ, KU-DNA-PKcs-Ligase 4-dependent) are error-prone processes; however, these are overstatements, and many of the mutagenic end-joining repair events arise in fact from the alternative pathways, as discussed $[79,87,88]$. Indeed, beside C-NHEJ, highly error-prone alternative(s) end-joining (A-EJ) process(es), also called alt-NHEJ, B-NHEJ (back-up NHEJ), MMEJ (micro-homology mediated end-joining) have been described that inevitably leads to the deletion of the intervening sequence (Figure 4) $[87,89,90]$. In contrast with C-NHEJ, A-EJ is KU-Ligase 4-independent, but is dependent on PARP1 (for review see [64,65]). Moreover, like HR, A-EJ is initiated by resection of the DSB by MRE11 [91-93].

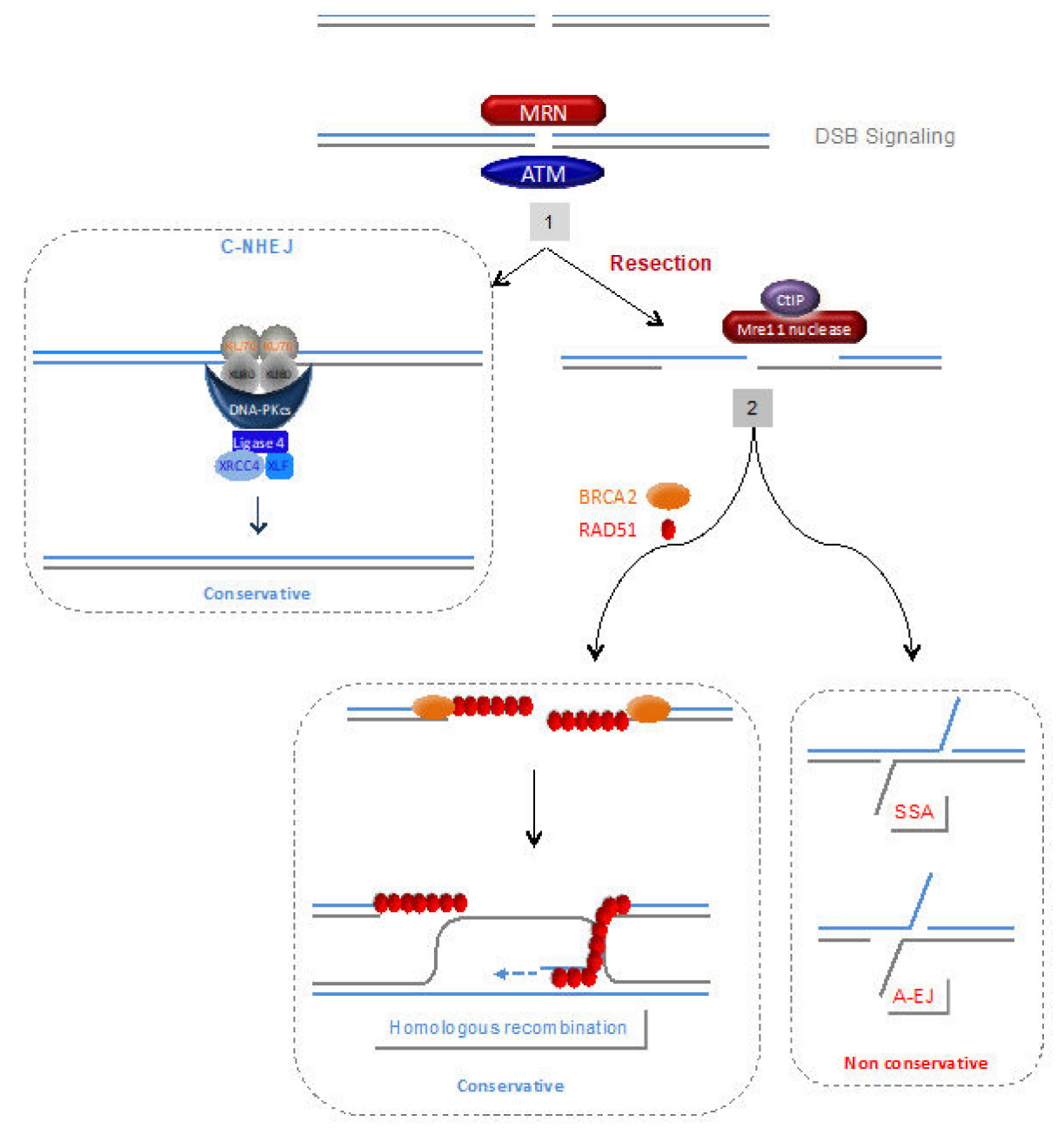

Figure 4. The 2-step DSB repair pathway choice model $[79,87,91]$. After signalling of the DSB by ATM and MRN, the selection of the DSB repair process act in two successive steps: (1) competition between the canonical NHEJ (C-NHEJ) pathway (KU/DNA-PKcs/ligase 4-dependent) versus resection. Note that C-NHEJ is conservative for DSB repair (for review see $[79,87]$ ). The nuclease activity of MRE11 and CtIP favour ssDNA resection, which can then at the second alternative step (2) initiate the conservative homologous recombination (HR) versus non-conservative single-strand annealing (SSA) or alternative end-joining (A-EJ) pathways. Loading of RAD51 on resected ssDNA, by BRCA2, engages DSB repair toward HR. The RAD51 nucleoprotein filament invades the intact homologous duplex DNA, priming DNA synthesis and the intact DNA molecule is copied, creating a D-Loop. 
Because, in contrast with C-NHEJ, both HR and alternative end-joining (A-EJ) (and single strand annealing, SSA, see below) are initiated by resection of the DSB generating single strand DNA (ssDNA) we have propose that the choice of the DSB repair pathway acts in two steps: 1- C-NHEJ versus resection; 2- HR versus non-conservative A-EJ or SSA (Figure 4) [79,91,94].

Single strand annealing (SSA) can repair DSB through a homology-mediated process (Figure 4). In this process, the resection of the DSB uncovers two complementary ssDNA tails. The annealing of this two complementary ssDNA repair DSB to the cost of the deletion of the intervener sequence. The annealing step is different from the strand invasion/exchange step performed by RAD51 for HR (see Figure 4 lower left panel); therefore SSA is RAD51-independent [95,96].

HR allows the use of the sister chromatids for the restart of the arrested replication forks. In addition, HR factors, such as RAD51 and BRCA2, protect the arrested replication forks from exonucleolytic single-stranded DNA degradation (resection) initiated by MRE11 [97,98]. C-NHEJ can also seal the DNA ends from collapsed replication forks, reconstituting the continuity of the DNA molecule and thus fostering the resumption of the arrested replication forks. However, on such DNA ends, NHEJ leads to genome rearrangement (for review [79,99]).

Remarkably, the DSB repair processes (mainly C-NHEJ) are critical for the diversity of T and B cells and for an effective adaptive immunity, such as the V(D)J recombination, class-switch recombination and somatic hypermutation (SHM) $[100,101]$. Of note, R loops have been linked to the regulation of antibody gene diversification [102] and class switch recombination (CSR), which results in the production of the various antibody isotypes that serve crucial effector functions during the humoral immune response $[103,104]$. $\mathrm{R}$ loops form during transcription of switch recombination sequences in vitro and in vivo, and there is solid evidence that $\mathrm{R}$ loops are required for efficient class switching. The classical model of $\mathrm{R}$ loops posits that they boost mutation rates by generating stable and long tracts of single-stranded DNA that serve as the substrate for activation induced deaminase (AID) [105], the enzyme that initiates the CSR reaction cascade by co-transcriptionally mutating ssDNA in switch recombination sequences [106-109]. Though logical and compelling, this model has not been supported by in vivo evidence. Indeed, several reports suggest that $\mathrm{R}$ loops may not be involved in recruiting AID activity to switch regions, meaning that $\mathrm{R}$ loops probably serve other unanticipated roles in CSR.

Ataxia telangiectasia (A-T), a syndrome associated with impaired DDR, also exhibits pronounced immunodeficiency symptoms [110-112]. In other cases, defects in C-NHEJ provoke severe combined immunodeficiency (SCID) [113,114].

In addition to affecting the DSBs' repair efficiency and accuracy, a defect in the DSB repair pathways also impacts innate immunity activation, as discussed below.

\subsubsection{Poly-ADP Ribose Polymerase (PARP1)}

The replicative stress response should ensure the identification and signalling of single strand breaks for its processing. PARP1 (a poly-ADP ribose polymerase) plays a multifaceted role in the cellular response to DNA damage, with evidences for involvement in multiple pathways of DNA damage repair and genome maintenance (for review: $[115,116]$ ). The existing roles of PARP1 within repair pathways are detection of DNA damage, poly(ADP-ribose) mediated recruitment of repair factors, and in poly(ADP-ribose) mediated regulation of biochemical activities. PARP-1 has now been implicated in maintenance of replication fork stability [117-120] in the regulation of HR [121,122], C-NHEJ [123,124]), A-EJ, nucleotide excision repair (NER) [125,126], DNA mismatch repair (MMR) [127], and base excision repair (BER) [128-130].

It has been shown that inactivation of PARP1 enhances DNA damage and micronuclei-dependent STING activation after replicative stress. In addition to its DNA repair function, PARP1 serves as a transcriptional co-activator in the NF- $\mathrm{KB}$ dependent pro-inflammatory transcription response [131]. PARP1 has a direct role in NF- $\mathrm{KB}$-mediated transcription. Indeed, the expression of NF- $\mathrm{kB}-$ dependent pro-inflammatory mediators, such as tumor necrosis factor alpha (TNF $\alpha$ ), interleukin-6 (IL-6), or inducible nitric oxide synthase (iNOS), is impaired in Parp 1-/- mice [132,133]. Of note, PARP-1 impacts 
the expression of these NF- $\mathrm{BB}$-dependent pro-inflammatory mediators by inducing the translocation of NF- $\mathrm{BB}$ into the nucleus upon genotoxic stress (reviewed in [134]). PARP1 physically interacts with both major subunits of NF-kB (p65 and p50) and is required for NF- $\mathrm{kB}-$ dependent gene transcription [132]. PARP1 is also acetylated by the histone acetylase p300/CREB-binding protein (CBP) upon inflammatory stimuli, leading to a stronger association with NF-KB [135]. Hassa et al. also showed that neither the DNA binding nor the enzymatic activity of PARP1 was necessary for the direct transcriptional activation of NF-кB [131]. Therefore, in the context of the replicative stress-mediated inflammatory response, PARP1 exhibits two opposite roles: on one side, by fostering DNA repair PARP1 prevents the activation of the STING-mediated inflammatory response; on the other side, as a co-factor of NF- $k \mathrm{~B}$, PARP1 plays a direct active role in the induction the pro-inflammatory transcriptional program.

\subsubsection{ATR and Chk1}

The innate immune receptor NKG2D is mostly expressed in NK cells and induces degranulation and cytokine production; thus, contributing to inflammation and NK-mediated cytotoxicity [33]. The recognition of NKG2D ligand (NKG2DL) by the NKG2D receptor greatly contributes to the detection and removal of infected or cancer cells [136]. The DNA damage sensor kinases ATM and ATR, as well as the downstream checkpoint kinase CHK1, were implicated in NKG2DL induction [33]. Ligand upregulation was prevented by pharmacological or genetic inhibition of ATR, ATM or CHK1.

\subsubsection{Ataxia Telangiectasia-Mutated (ATM)}

ATM is a kinase that plays a key pivotal role in mediating DSB signal transduction for DDR initiation (Figure 3, Figure 4). ATM deficiency causes the ataxia telangiectasia (A-T) syndrome, which is associated with persistent genome instability [137]. The development of a complex multi-organ disease in A-T patients has been proposed to stem from the deregulation of the immune response leading to autoimmunity and chronic inflammation, arising from persistent genome instability in these patients [77]. Fibroblasts from A-T accumulate DNA fragments in the cytoplasm that are recognized by PRRs, inducing an inflammatory response [77,138], which can promote senescence and inhibit stem cell functions [59]. Elevated type I IFN signalling was associated with the ATM deficiency in cultured fibroblasts cell $[59,139]$ and in the sera of human A-T patients and of ATM-null mice [77]. Moreover, ATM-/- mice present with infiltration of neutrophils and lymphocytes in the lungs and increased mRNA levels of pro-inflammatory cytokines, e.g., IL-6 and TNF [140]. Hartlova and collaborators showed that immune activation in A-T patients is driven by damaged DNA in the nucleus that is recognized by the cytosolic innate immune sensor STING [77]. The autoinflammatory phenotype of A-T is abrogated in Atm-/-Sting-/- double knockout mice and significantly reduced after cGAS knockdown, suggesting that the cGAS-STING pathway plays an essential role in the induction of innate immunity upon the accumulation/persistence of DNA damage [77].

\subsubsection{The MRN (MRE11/RAD50/NBS1) Complex}

The MRN complex is involved both in the early steps of DSB signalling and in the DSB repair mechanism itself, fostering ssDNA resection necessary to initiate HR, as well as alternative DSB repair (Figures 3 and 4) [79,141-146].

Hypomorphic NBS alleles exhibit an impaired inflammatory response [147], and a loss of NBS1 leads to exacerbated inflammation [148]. Conditional Nbs1 inactivation in hair follicle (HF) progenitors promotes cytokines secretion and leads to an immune response resembling psoriasiform dermatitis. Additionally, simultaneous Nbs1 and p53 loss, enhance pro-inflammatory cytokines expression and exacerbate this inflammatory phenotype [149]. Moreover, RAD50 interacts with the innate immune system adaptor CARD9 to produce IL-1 [150].

Cells with a mutation in the MRE11 gene, derived from a patient with ataxia-telangiectasia-like disorder, and cells in which MRE11 was knocked down had defects in dsDNA-induced type I IFN production. Remarkably, MRE11 physically interacted with dsDNA in the cytoplasm and was required 
for activation of the stimulator of IFN genes (STING) and IRF3 [151]. RAD50 was also required for dsDNA responses, whereas NBS1 was dispensable.

MRE11 is also involved in the resection of arrested replication forks, a process counteracted by the HR proteins BRCA2 and RAD51 [97,98]. It has been proposed that MRE11-mediated degradation of the newly replicated genome and the accumulation of these self-DNA fragments in the cytoplasm trigger the activation of STING-mediated innate immune signalling [64]. However, the data observed in Aicardi-Goutières syndrome (AGS), which results from mutation in the SAMHD1 gene, revealed an antagonist role for MRE11, which protects against the production of cytosolic DNA upon replication stress and the subsequent production of interferon [63] (see below). Thus, MRE11 plays 3 roles: it is involved in the signalling of DSBs, in resection initiation and in the signalling of cytosolic DNA.

\subsubsection{SAMHD1 and Aicardi-Goutières Syndrome (AGS)}

SAMHD1 protects against virus proliferation through its dNTPase activity that degrades nucleotides. A mutation in SAMHD1 can cause AGS [152], an inheritable neurological disease that leads to microcephaly, intellectual disability, and childhood death [153]. It has been proposed that chronic hyper-IFN signalling drives AGS symptoms [154]. Recessive mutations in genes involved in nucleic acid metabolism, such as TREX1, RNASEH2b and SAMHD1 cause AGS [153]. TREX1 (3' repair exonuclease 1) degrades cytosolic DNA, preventing the induction of cGAS-STING-dependent inflammation [155-160]. RNASEH2 degrades RNA/RNA hybrids; thus, avoiding the conflict of replication versus transcription and the resulting replication stress. It should be noted that in RNaseH2-deficient mice, the genetic depletion of STING or cGAS can reverse the ensuing inflammation and autoimmune phenotypes [71,161].

In collaboration with MRE11 and CtIP, SAMHD1 is also involved in resection at endonuclease-induced DSBs and arrested replication forks, i.e., in genomic DNA [60,162]. In SAMHD1-depleted cells, MRE11-dependent resection of stalled replication forks is replaced by the RecQ1 helicase unwinding of the DNA; then, by cleaving the DNA flap generated, an endonuclease generates ssDNA fragments that accumulate in the cytosol, where they activate the cGAS-STING pathway, inducing the expression of pro-inflammatory type I IFN. By favouring MRE11 activity at arrested replication forks (instead of RecQ1), SAMHD1 thus protects against such a response, preventing chronic inflammation by limiting the release of ssDNA from stalled replication forks [60].

\subsection{Homologous Recombination (HR)}

RAD51 plays a pivotal role at the central step of HR, i.e., the search for homology and strand exchange. RAD51 is loaded on resected ssDNA by BRCA2 (Figure 4). Moreover, in addition to promoting the search for homology and strand exchange, RAD51 and BRCA2 protect arrested replication forks from extensive degradation by MRE11/SAMHD1 (Figure 4). Then, RAD51 helps the restart of the arrested replication forks using the sister chromatid as a template (Figure 2B). RAD51 thus plays a pivotal role in genome plasticity. It is noteworthy that BRCA1, which elicits the ssDNA resection and thus HR initiation, and BRCA2 are frequently mutated in familial ovary and breast cancer $[163,164]$. Many genes directly or indirectly controlling HR are mutated in Fanconi anaemia (FA) syndrome, which is associated with developmental defects, genetic instability, bone marrow failure and cancer predisposition.

Inhibiting RAD51 functions leads to replication stress, which then generates mitosis defects, uneven chromosome segregation and micronuclei formation $[68,165]$. Moreover, in the absence of RAD51, the unprotected newly replicated sequences are degraded by the exonuclease activity of MRE11, and the fragmented nascent DNA accumulates in the cytosol, initiating triggering the activation of STING-mediated innate immune signalling [64].

BRCA2 inactivation also leads to pro-inflammatory cytokine production, including $\mathrm{TNF} \alpha$, and increases sensitivity to TNF $\alpha$. Enhanced TNF $\alpha$ sensitivity is also present in BRCA1 or FANCD2 inactivation [166]. BRCA2 inactivation leads to cGAS-positive micronuclei and results in a cell-intrinsic 
interferon response (cGAS/STING-mediated interferon response), which encompasses rewired TNF $\alpha$ signalling and enhances TNF $\alpha$ sensitivity [166].

Defects in BRCA1 result in the constitutive activation of the STING pathway in response to accumulation of cytosolic DNA $[49,167]$. Additionally, BRCA1 plays a hitherto unidentified role as a cofactor to IFI16 in the nuclear innate sensing of foreign DNA and the subsequent assembly and cytoplasmic distribution of stable IFI16-inflammasomes leading to IL-1 $\beta$ formation, as well as the induction of IFN- $\beta$ via cytoplasmic signalling through IFI16, STING, TBK1 and IRF3 [168].

\subsubsection{Resolution of HR and Arrested Replication Forks Intermediates}

Reversion and resumption of arrested replication forks, and HR intermediates (Holliday junctions), generate branched DNA structures that are resolved by cleavage or dissolution [6,67,79]. A defect in these activities leads to accumulation of such branched structures that are toxic and can generate genetic instability [169].

a-SLX4 and MUS81

SLX4 is a platform protein that recruits nucleases that resolve branched DNA intermediates resulting from HR and/or arrested replication fork processing. MUS81 is an endonuclease is an endonuclease that interacts with SLX4 and plays a role in resolving HR intermediates, suppressing chromosomal instability [170]. MUS81 fosters the accumulation of fragmented self-DNA (including DNA lesions, R-loops, repetitive sequences and common fragile sites) resulting from replication stress, leading to STING-dependent expression of type I IFNs and chemokines [171]. SLX4 is mutated in FA Group P. Fibroblasts from FA-P harbour cytoplasmic DNA accumulation, including sequences deriving from active Long INterspersed Element-1 (LINE-1), triggering the cGAS-STING pathway that elicits IFN expression. Similar results were obtained with FA-D2, an upstream activator of SLX4, which caused the accumulation of DNA fragments in the cytoplasm that are recognized by PRRs, inducing an inflammatory response [138] leading to senescence and inhibiting stem cell function [58]. In vitro, stimulated FA bone marrow showed elevated levels of tumour necrosis factor- $\alpha$ (TNF- $\alpha)$ and IFN- $\gamma$ [172]. Sumpter et al. suggest that FA genes function in the selective autophagy of genetically distinct viruses, in mitochondrial quality control and in preventing inflammasome activation due to mitochondrial reactive oxygen species (ROS) [173].

b-RecQ helicases

The RecQ helicase family contains five members, including RecQ1, RecQ2, RecQ4 (mutated in Rothmund-Thomson syndrome), Bloom syndrome (BLM) and Werner syndrome (WRN). Many of these helicases are involved in the processing of HR and replication stress intermediates.

As discussed above, the ablation of SAMHD1 decreases MRE11-mediated resection of arrested replication forks; the resection at blocked forks is then performed by RecQ1, which unpairs the two DNA strands, after which an endonuclease that cleaves the displaced ssDNA strand then produces a piece of DNA that can be exported to the cytoplasm, triggering the production of IFN1 through the STING pathway [63].

BLM is deficient in Bloom syndrome (BS), a rare genetic disease characterized by genome instability, increased sister chromatids exchanges, accumulation of micronuclei, susceptibility to cancer and immunodeficiency [174]. BLM-deficient fibroblasts show constitutive upregulation of inflammatory interferon-stimulated gene (ISG) expression, which is mediated by the cGAS-STING-IRF3 cytosolic DNA-sensing pathway [73]. Moreover, increased DNA damage or downregulation of the cytoplasmic exonuclease TREX1 enhances ISG expression in BLM-deficient fibroblasts, and BS patients show elevated ISG expression in the peripheral blood [73]. BLM, in association with Dna2 and EXO1, has been reported to promote long-range ssDNA resection $[175,176]$. In contrast with MRE11 and $\mathrm{CtIP}$, depletion of these factors suppressed the increase in signal of short cytoplasmic ssDNA detected in cells treated with ionizing radiation (IR), mitomycin C or cisplatin, which activated the innate 
immune response, and TREX1 deficiency exacerbated these responses [65]. The absence of involvement of MRE11 and CtIP may suggest that only long-range resection produces reactive ssDNA species. Moreover, in contrast, BLM has also been reported to protect against ssDNA resection through the loading of 53BP1 on DSBs in the G1 phase but not in the S/G2 phase [177]. Collectively, these data suggest that the role of BLM in generating cytosolic DNA acts in the $S$ phase, thus as a consequence of replication stress.

A deficiency in WRN leads to Werner syndrome (WS), which is associated with genetic instability, cancer predisposition and premature ageing [178-180]. Fibroblasts derived from WS patients or from mutant mice and serum from WS patients show increased inflammatory signalling characterized by expression changes in HIF-1, IL-6 and components of the NF-kB pathway [181-183].

\subsection{C-NHEJ}

DNA-dependent protein kinase (DNA-PK) is formed by the association of the heterodimer KU70-KU80 with DNA-PKcs (DNA-PK catalytic subunit). DNA-PKcs is the catalytic subunit of the kinase that plays a central role in C-NHEJ regulation (Figure 4). Germline mutations affecting DNA-PKcs lead to severe combined immunodeficiency (SCID) [184]. Indeed, DNA-PKcs is required for $\mathrm{V}(\mathrm{D}) \mathrm{J}$ recombination, which utilizes the NHEJ pathway to promote antigen diversity in the adaptive immune system. Additionally, the Activation Induced Cytidine Deaminase (AID) also helps in generation of immunoglobulin diversity by mediating somatic hypermutation and gene conversion [185].

DNA-PKcs interacts with DNA in the cytoplasm and is critical for inducing innate immune responses to DNA and viral DNA in fibroblasts [186-188]. A novel role for DNA-PK in activating innate immunity and the inflammatory response independently of NF- $\mathrm{B}$ has been, thus, suggested [186]: the DNA from various pathogens is bound by DNA-PK, resulting in IRF-3-mediated transcription of multiple cytokine and chemokine genes independently of DNA-PKcs kinase activity [186]. Furthermore, evidence shows that KU70 induces IFN- $\lambda 1$ production by activating the IFN regulatory factors IRF-1 and IRF-7 in response to cytosolic DNA [188,189].

\subsection{Other DNA Repair Pathways}

The excision repair pathways, nucleotide excision repair (NER), base excision repair (BER) and mismatch repair (MMR) repair a variety of DNA lesions. NER is specific for the repair of bulky adduct DNA damage [190-192], while BER is responsible for removing damaged bases containing small oxidative and alkyl adducts [193-197]. The MMR pathway is capable of repairing single base mismatches and a variety of small insertions and deletions to the genome [198,199]. Chronic innate immune activity was detected and found to cause tissue deterioration in NER-deficient ERCC1 mutant mice [200,201]. Immunological symptoms are also present in mice lacking OGG1, a DNA glycosylase playing a pivotal role in BER [202,203] and in APE2-deficient mice (AP endonuclease involved in BER) [204]. Moreover, another BER glycosylase, the apurinic/apyrimidinic endonuclease 1 (APE1), has been associated with the activation of immune signalling [205]. In a preclinical murine model, the isogenic introduction of a mutation in the central MMR player MSH2 (MutS homologue 2) resulted in marked improvements in the immune response [206,207].

\section{DDR and Autoimmune Disease}

Autoantibodies against the KU antigen, which were originally described in patients with scleroderma-polymyositis overlap syndrome, are also found in many autoimmune diseases, particularly in patients with systemic lupus erythematosus (SLE), systemic sclerosis (SSc), and undifferentiated connective tissue disease (UCTD) [208]. Autoantibodies against KU, DNA-PKcs, poly-ADP ribose polymerase (PARP), and against DNA repair proteins such as WRN and MRE11 have been identified in the serum of patients having systemic autoimmune rheumatic disease (SARD) [209]. Another study reflecting the role of DNA damage in promoting autoimmune diseases showed that cell lines from 
patients with systemic lupus erythematosus (SLE) have a defective DSB repair [210]. In the same context, Bawadekar et al. (2015) have shown the presence of IFI16 in the sera of systemic-autoimmune patients associated with an upregulation of cytokine-encoding genes in endotoxin-free recombinant IFI16 (rIFI16) endothelial cells. IFI16 seemed to promote inflammation in endothelial cells through the activation of p38 MAPK and NF-кB p65 [211]. Finally, Karakasilioti et al. (2013) showed that persistent DNA damage signalling in mice, carrying a defective NER only in adipose tissues, triggers a chronic autoinflammatory response leading to fat depletion and metabolic abnormalities [200].

\section{Reactive Oxygen Species and Nitrogen Species}

Reactive oxygen species (ROS) comprise of a family of short-lived molecules, such as $\mathrm{O}_{2}{ }^{-}, \mathrm{H}_{2} \mathrm{O}_{2}$ and $\bullet \mathrm{OH}$ [212]. ROS can potentially alter every kind of biological molecules. For example, ROS can generate DNA damage and can affect replication dynamics through different processes, including DNA damage that impairs polymerase progression, imbalance of the nucleotide pools (through oxidation of the ribonucleotide reductase), oxidation of proteins of the replisome. Nitrogen species (RNS) can also damage DNA to form mutagenic lesions, 8-nitroguanine [2,213-216].

On the other hand, ROS can exercise active roles as secondary messengers in physiological processes [217]. Many functional roles of ROS have been shown in cells from aiding immunity (e.g., oxidative bursts in phagocytes to eliminate pathogens) [218] to acting as signalling molecules (e.g., $\mathrm{H}_{2} \mathrm{O}_{2}$ regulating NFKB, MAPK pathways) [219].

ROS are produced endogenously by mitochondria (where $\mathrm{O}_{2}$ acts as a terminal electron acceptor for electron transport chain) [220], NADPH oxidase, a cell membrane bound enzyme [221], peroxisomes (which contain enzymes that produce $\mathrm{H}_{2} \mathrm{O}_{2}$ e.g., polyamine oxidase) [222], endoplasmic reticulum (produce $\mathrm{H}_{2} \mathrm{O}_{2}$ as a by-product during protein folding); or upon exposure to exogenous stress like ionizing radiation (IR), chemotherapeutic drugs and environmental insults, which affect the organelles and enzymes listed above [223]. Depending on the source of ROS, cell type, and tissue environment, ROS signalling may participate in normal physiological processes or contribute to a maladaptive response that leads to metabolic dysfunction and inflammatory signalling. ROS can generate cytosolic DNA, which is sensed by cGAS within tumours. The cGAS, in turn, activates STING to upregulate the expression of type 1 IFN, ISG and SASP genes [224]. The oxidized base 8-hydroxyguanosine (8-OHG), a marker of oxidative damage in DNA, potentiated cytosolic immune recognition by decreasing its susceptibility to repair exonuclease1 (TREX1)-mediated degradation. Thus, oxidized DNA represents a prototypic damage-associated molecular pattern (DAMP) with important implications for infection, sterile inflammation and autoimmunity [225]. Mitochondria-derived ROS can induce activation of innate immune responses, including activation of inflammasome, cGAS-STING and NF- $\mathrm{kB}$ signalling pathways (for review: [226]). The ambient levels of ROS are important for homeostasis of cells, whereas excessive ROS are important in killing pathogens. If ROS are not controlled by an array of sophisticated antioxidant mechanisms, it leads to inflammatory tissue injury [227].

\section{A Vicious Circle}

Under inflammation, ROS and RNS are produced in inflammatory and epithelial cells causing damages to a wide variety of biomolecules including nucleic acids, proteins and lipids [228,229]. Under inflammatory conditions, nitric oxide (NO) is generated in inflammatory and epithelial cells, and this reaction is catalysed by NO synthase (NOS), especially inducible nitric oxide synthase (iNOS). NO and NOS are known to play roles on both pro- and anti-carcinogenic effects [230]. Sustained induction of iNOS in chronic inflammation can produce ROS and RNS, causing DNA damage [231].

\section{Implications for Immunotherapy}

Alterations in DNA repair and replicative stress can influence either the adaptive immune system, by increasing the number of mutations/neoantigens leading to increases in the foreignness of a tumour/antigenicity [232], or both the innate and adaptive immune systems, by changing the cell 
microenvironment. Neoantigens result from mutations and encode immunologically active proteins that can cause the immune system to recognize the affected cell as foreign. Defects in DNA repair may influence the adaptive immune system by leading to an increased number of mutations and subsequently to an increased number of neoantigens, which in turn increases the foreignness of a tumour (i.e., antigenicity), resulting in a higher probability of tumour recognition by the immune system. DNA repair could also influence how the innate immune system initially responds to a tumour and recruits the adaptive immune system to the site of malignancy. DNA repair deficiency is associated with upregulation of immune checkpoints and immune cell-infiltrated microenvironments. While activation of immune pathways such as STING in the acute phase promotes an antitumourigenic response, in the chronic phase, DNA damage repair-deficient tumours instead exploit this STING-mediated immune response, tailoring it to promote a proinvasive microenvironment favouring tumour growth. Indeed, defects in DDR improve the recognition of tumours by the adaptive immune system [233]. Before the adaptive immune system can recognize a tumour as foreign, immune cells must be recruited to the site of the tumour.

In vivo studies revealed that chemotherapy [234] and ionizing radiation treatment [235-237] induce type I IFN signalling in tumours to promote antitumour immunity. Burdette et al. suggested that this recognition is often mediated by STING activation [45], highlighting the important role that the cGAS-STING pathway plays in innate immune response activation during tumour progression. Even though cGAS-STING has pro- and antitumourigenic roles, depending on the context $[35,46,238]$, this pathway has been suggested as necessary for a therapeutic response in immunotherapy. Studies performed in a syngeneic MC38 murine tumour model showed that the knockout of STING significantly reduced tumour control after single-dose ionizing radiation [237]. Similar to exogenous DNA damage, inherent DNA repair defects in tumours may also increase the production of cytosolic DNA and appear to similarly trigger a cGAS-STING response [77]. Indeed, blocking $\mathrm{T}$ cell inhibitory pathways using immune checkpoint inhibitors is ineffective in mice lacking STING [69]. The ability of transformed cells to inactivate this pathway is supposed to create a selective advantage, as cGAS-STING signalling is suppressed in several tumours [239].

In opposition, the cGAS-STING pathway has pro-tumorigenic roles in contexts of inflammation -induced tumorigenesis [238]. For example, it has been shown that genetic inactivation of Sting in mice has an anti-tumorigenic effect in skin cancer induced by 7,12-dimethylbenz[a]anthracene (DMBA) [240] and colorectal cancer induced by azoxymethane (AOM) [241]. Additionally, STING can also participate on tumour progression. In a model of breast cancer, the activation of IFN-STAT1 signalling by STING enhanced cell survival and increased the resistance to DNA damage induced chemotherapy [242]. These results highlight the importance of context specificity to the use of STING inhibitors for cancer therapy.

In ovarian cancers, BRCA1/2-mutated tumours are associated with increased levels of tumour-infiltrating lymphocytes [243]. These patients show improved prognosis, and in addition to increased genomic instability, these tumours have more frequent STING activation [243]. In the same context, inactivation of replicative stress response factors (PARP1 and/or ATR inhibition) enhances the cGAS-STING-mediated interferon response after BRCA2 inactivation in human cell lines [74,244]. Similar results have been shown in small cell lung cancer (SCLC) after the inhibition of either PARP1 or CHK1 [245,246].

A synergic relationship between the inactivation of replicative stress response inhibitors and replicative stress factors has been shown in clinical trials [247,248]. The new findings on the interaction of replicative stress and the innate immune response provide exciting novelties that can impact the development of new therapeutic strategies for cancer.

\section{Conclusions}

Cells and organisms are inevitably subjected to exogenous and endogenous stresses that jeopardize genome integrity. Several levels of responses have been developed to face such stresses. At the cellular 
level, the DDR, programmed cell death and senescence programmes avoid the proliferation of cells bearing DNA damage and rearrangements. However, the second level of defences, at the organismal level, has emerged from recent studies: the activation of innate immunity by DNA injuries, thus allowing for the elimination of cells bearing DNA damage.

Indeed, an exciting new concept is the link between replication stress and the activation of the cell-intrinsic innate immune response. Many findings reveal that exposure to agents generating replication stress and replication stress-deficient cells engender the expression of pro-inflammatory cytokines and type I IFNs. This activation is mediated through the presence of cytosolic DNA. Remarkably, although this DNA corresponds to genomic DNA from the cell, it is recognized as a foreign DNA by the defence systems. Central to the innate immune response is the adaptor protein STING, which couples signals from cytosolic DNA sensors to a transcriptional response for the activation of type I IFN signalling axes, promoting elimination by the adaptive immune system. STING signalling is suppressed in several tumours, and multiple cancer cell types contain genome-derived cytosolic ssDNA, affirming the presence and importance of persistent replication stress in tumours. As type I IFN production from the innate response is critical in priming the adaptive immune system, robust STING signalling has been associated with an increased immunotherapy response. Future studies should allow for a better understanding of the interplay between replicative stress and the immune system and should provide insight into how these responses can be regulated optimally. This knowledge might also allow for the improvement of anticancer strategies connecting radio-/chemotherapies with immune therapy.

Author Contributions: S.R., G.M.-R. and B.S.L. wrote the article. All authors have read and agreed to the published version of the manuscript.

Funding: This work was supported by grants from the Ligue Nationale contre le cancer "Equipe labellisée 2020", ANR (Agence Nationale de la Recherche, ANR-16-CE12-0011-02 and ANR-16-CE18-0012-02), AFM-Téléthon and INCa (Institut National du Cancer, PLBIO18-232). GMR was supported by a fellowship from Ligue Nationale contre le cancer.

Conflicts of Interest: The authors declare no conflict of interest.

\section{References}

1. Negrini, S.; Gorgoulis, V.G.; Halazonetis, T.D. Genomic instability-An evolving hallmark of cancer. Nat. Rev. Mol. Cell Biol. 2010, 11, 220-228. [CrossRef]

2. Wilhelm, T.; Ragu, S.; Magdalou, I.; Machon, C.; Dardillac, E.; Técher, H.; Guitton, J.; Debatisse, M.; Lopez, B.S. Slow Replication Fork Velocity of Homologous Recombination-Defective Cells Results from Endogenous Oxidative Stress. PLoS Genet. 2016, 12. [CrossRef]

3. Somyajit, K.; Gupta, R.; Sedlackova, H.; Neelsen, K.J.; Ochs, F.; Rask, M.B.; Choudhary, C.; Lukas, J. Redox-sensitive alteration of replisome architecture safeguards genome integrity. Science 2017, 358, 797-802. [CrossRef]

4. Mirkin, E.V.; Mirkin, S.M. Replication fork stalling at natural impediments. Microbiol. Mol. Biol. Rev. 2007, 71, 13-35. [CrossRef]

5. Zeman, M.K.; Cimprich, K.A. Causes and consequences of replication stress. Nat. Cell Biol. 2014, 16, 2-9. [CrossRef]

6. Magdalou, I.; Lopez, B.S.; Pasero, P.; Lambert, S.A.E. The causes of replication stress and their consequences on genome stability and cell fate. Semin. Cell Dev. Biol. 2014, 30, 154-164. [CrossRef]

7. Dutta, D.; Shatalin, K.; Epshtein, V.; Gottesman, M.E.; Nudler, E. Linking RNA polymerase backtracking to genome instability in E. coli. Cell 2011, 146, 533-543. [CrossRef]

8. Merrikh, H.; MacHón, C.; Grainger, W.H.; Grossman, A.D.; Soultanas, P. Co-directional replication-transcription conflicts lead to replication restart. Nature 2011, 470, 554-558. [CrossRef]

9. Sankar, T.S.; Wastuwidyaningtyas, B.D.; Dong, Y.; Lewis, S.A.; Wang, J.D. The nature of mutations induced by replication-transcription collisions. Nature 2016, 535, 178-181. [CrossRef]

10. Srivatsan, A.; Tehranchi, A.; MacAlpine, D.M.; Wang, J.D. Co-orientation of replication and transcription preserves genome integrity. PLoS Genet. 2010, 6. [CrossRef] 
11. García-Muse, T.; Aguilera, A. Transcription-replication conflicts: How they occur and how they are resolved. Nat. Rev. Mol. Cell Biol. 2016, 17, 553-563. [CrossRef] [PubMed]

12. Aguilera, A.; Garcia-Muse, T. R loops: From transcription byproducts to threats to genome stability. Mol. Cell 2012, 46, 115-124. [CrossRef] [PubMed]

13. Huertas, P.; Aguilera, A. Cotranscriptionally formed DNA:RNA hybrids mediate transcription elongation impairment and transcription-associated recombination. Mol. Cell 2003, 12, 711-721. [CrossRef] [PubMed]

14. Paulsen, R.D.; Soni, D.V.; Wollman, R.; Hahn, A.T.; Yee, M.C.; Guan, A.; Hesley, J.A.; Miller, S.C.; Cromwell, E.F.; Solow-Cordero, D.E.; et al. A Genome-wide siRNA Screen Reveals Diverse Cellular Processes and Pathways that Mediate Genome Stability. Mol. Cell 2009, 35, 228-239. [CrossRef] [PubMed]

15. Santos-Pereira, J.M.; Aguilera, A. R loops: New modulators of genome dynamics and function. Nat. Rev. Genet. 2015, 16, 583-597. [CrossRef]

16. Sollier, J.; Stork, C.T.; García-Rubio, M.L.; Paulsen, R.D.; Aguilera, A.; Cimprich, K.A. Transcription-Coupled Nucleotide Excision Repair Factors Promote R-Loop-Induced Genome Instability. Mol. Cell 2014, 56, 777-785. [CrossRef] [PubMed]

17. Macheret, M.; Halazonetis, T.D. DNA Replication Stress as a Hallmark of Cancer. Annu. Rev. Pathol. Mech. Dis. 2015, 10, 425-448. [CrossRef]

18. Bartek, J.; Bartkova, J.; Lukas, J. DNA damage signalling guards against activated oncogenes and tumour progression. Oncogene 2007, 26, 7773-7779. [CrossRef]

19. Bartkova, J.; Horejsi, Z.; Koed, K.; Kramer, A.; Tort, F.; Zieger, K.; Guldberg, P.; Sehested, M.; Nesland, J.M.; Lukas, C.; et al. DNA damage response as a candidate anti-cancer barrier in early human tumorigenesis. Nature 2005, 434, 864-870. [CrossRef]

20. Gorgoulis, V.G.; Vassiliou, L.V.; Karakaidos, P.; Zacharatos, P.; Kotsinas, A.; Liloglou, T.; Venere, M.; Ditullio, R.A.J.; Kastrinakis, N.G.; Levy, B.; et al. Activation of the DNA damage checkpoint and genomic instability in human precancerous lesions. Nature 2005, 434, 907-913. [CrossRef]

21. Roos, W.P.; Thomas, A.D.; Kaina, B. DNA damage and the balance between survival and death in cancer biology. Nat. Rev. Cancer 2016, 16, 20-33. [CrossRef] [PubMed]

22. Agathangelou, K.; Apostolou, Z.; Garinis, G.A. Nuclear DNA damage and ageing. In Biochemistry and Cell Biology of Ageing: Part I Biomedical Science. Subcellular Biochemistry; Springer: Singapore, 2018; Volume 90, pp. 309-322.

23. Surova, O.; Zhivotovsky, B. Various modes of cell death induced by DNA damage. Oncogene 2013, 32, 3789-3797. [CrossRef] [PubMed]

24. Jackson, S.P.; Bartek, J. The DNA-damage response in human biology and disease. Nature 2009, 461, 1071-1078. [CrossRef] [PubMed]

25. Ciccia, A.; Elledge, S.J. The DNA Damage Response: Making It Safe to Play with Knives. Mol. Cell 2010, 40, 179-204. [CrossRef] [PubMed]

26. Tiwari, V.; Wilson, D.M. DNA Damage and Associated DNA Repair Defects in Disease and Premature Aging. Am. J. Hum. Genet. 2019, 105, 237-257. [CrossRef] [PubMed]

27. Da Silva, P.F.L.; Schumacher, B. DNA damage responses in ageing. Open Biol. 2019, 9. [CrossRef] [PubMed]

28. Hoeijmakers, J.H. DNA damage, aging, and cancer. N. Engl. J. Med. 2009, 361, 1475-1485. [CrossRef]

29. Newton, K.; Dixit, V.M. Signaling in innate immunity and inflammation. Cold Spring Harb. Perspect. Biol. 2012, 4. [CrossRef]

30. Cao, X. Self-regulation and cross-regulation of pattern-recognition receptor signalling in health and disease. Nat. Rev. Immunol. 2016, 16, 35-50. [CrossRef]

31. Paludan, S.R.; Bowie, A.G. Immune Sensing of DNA. Immunity 2013, 38, 870-880. [CrossRef]

32. Roers, A.; Hiller, B.; Hornung, V. Recognition of Endogenous Nucleic Acids by the Innate Immune System. Immunity 2016, 44, 739-754. [CrossRef] [PubMed]

33. Gasser, S.; Orsulic, S.; Brown, E.J.; Raulet, D.H. The DNA damage pathway regulates innate immune system ligands of the NKG2D receptor. Nature 2005, 436, 1186-1190. [CrossRef] [PubMed]

34. Gasser, S.; Zhang, W.Y.L.; Tan, N.Y.J.; Tripathi, S.; Suter, M.A.; Chew, Z.H.; Khatoo, M.; Ngeow, J.; Cheung, F.S.G. Sensing of dangerous DNA. Mech. Ageing Dev. 2017, 165, 33-46. [CrossRef] [PubMed]

35. Gasser, S.; Raulet, D.H. The DNA damage response arouses the immune system. Cancer Res. 2006, 66, 3959-3962. [CrossRef] 
36. Li, T.; Chen, Z.J. The cGAS-cGAMP-STI NG pathway connects DNA damage to inflammation, senescence, and cancer. J. Exp. Med. 2018, 215, 1287-1299. [CrossRef]

37. Ablasser, A.; Chen, Z.J. CGAS in action: Expanding roles in immunity and inflammation. Science 2019, 363. [CrossRef]

38. Gao, P.; Ascano, M.; Wu, Y.; Barchet, W.; Gaffney, B.L.; Zillinger, T.; Serganov, A.A.; Liu, Y.; Jones, R.A.; Hartmann, G.; et al. Cyclic $\left[\mathrm{G}\left(2^{\prime}, 5^{\prime}\right) \mathrm{pA}\left(3^{\prime}, 5^{\prime}\right) \mathrm{p}\right]$ is the metazoan second messenger produced by DNA-activated cyclic GMP-AMP synthase. Cell 2013, 153, 1094-1107. [CrossRef]

39. Ablasser, A.; Goldeck, M.; Cavlar, T.; Deimling, T.; Witte, G.; Röhl, I.; Hopfner, K.P.; Ludwig, J.; Hornung, V. CGAS produces a 2'-5'-linked cyclic dinucleotide second messenger that activates STING. Nature 2013, 498, 380-384. [CrossRef]

40. Diner, E.J.; Burdette, D.L.; Wilson, S.C.; Monroe, K.M.; Kellenberger, C.A.; Hyodo, M.; Hayakawa, Y.; Hammond, M.C.; Vance, R.E. The Innate Immune DNA Sensor cGAS Produces a Noncanonical Cyclic Dinucleotide that Activates Human STING. Cell Rep. 2013, 3, 1355-1361. [CrossRef]

41. Sun, L.; Wu, J.; Du, F.; Chen, X.; Chen, Z.J. Cyclic GMP-AMP synthase is a cytosolic DNA sensor that activates the type I interferon pathway. Science 2013, 339, 786-791. [CrossRef]

42. Civril, F.; Deimling, T.; De Oliveira Mann, C.C.; Ablasser, A.; Moldt, M.; Witte, G.; Hornung, V.; Hopfner, K.P. Structural mechanism of cytosolic DNA sensing by cGAS. Nature 2013, 498, 332-337. [CrossRef] [PubMed]

43. Luecke, S.; Holleufer, A.; Christensen, M.H.; Jønsson, K.L.; Boni, G.A.; Sørensen, L.K.; Johannsen, M.; Jakobsen, M.R.; Hartmann, R.; Paludan, S.R. cGAS is activated by DNA in a length-dependent manner. EMBO Rep. 2017, 18, 1707-1715. [CrossRef] [PubMed]

44. Zhang, X.; Wu, J.; Du, F.; Xu, H.; Sun, L.; Chen, Z.; Brautigam, C.A.; Zhang, X.; Chen, Z.J. The cytosolic DNA sensor cGAS forms an oligomeric complex with DNA and undergoes switch-like conformational changes in the activation loop. Cell Rep. 2014, 6, 421-430. [CrossRef] [PubMed]

45. Burdette, D.L.; Monroe, K.M.; Sotelo-Troha, K.; Iwig, J.S.; Eckert, B.; Hyodo, M.; Hayakawa, Y.; Vance, R.E. STING is a direct innate immune sensor of cyclic di-GMP. Nature 2011, 478, 515-518. [CrossRef] [PubMed]

46. Motwani, M.; Pesiridis, S.; Fitzgerald, K.A. DNA sensing by the cGAS-STING pathway in health and disease. Nat. Rev. Genet. 2019, 20, 657-674. [CrossRef] [PubMed]

47. Shang, G.; Zhang, C.; Chen, Z.J.; Bai, X.C.; Zhang, X. Cryo-EM structures of STING reveal its mechanism of activation by cyclic GMP-AMP. Nature 2019, 567, 389-393. [CrossRef]

48. Zhang, C.; Shang, G.; Gui, X.; Zhang, X.; Bai, X.C.; Chen, Z.J. Structural basis of STING binding with and phosphorylation by TBK1. Nature 2019, 567, 394-398. [CrossRef]

49. Ishikawa, H.; Barber, G.N. STING is an endoplasmic reticulum adaptor that facilitates innate immune signalling. Nature 2008, 455, 674-678. [CrossRef]

50. Ishikawa, H.; Ma, Z.; Barber, G.N. STING regulates intracellular DNA-mediated, type i interferon-dependent innate immunity. Nature 2009, 461, 788-792. [CrossRef]

51. Tojima, Y.; Fujimoto, A.; Delhase, M.; Chen, Y.; Hatakeyama, S.; Nakayama, K.; Kaneko, Y.; Nimura, Y.; Motoyama, N.; Ikeda, K.; et al. NAK is an I kappa B kinase-activating kinase. Nature 2000, 404, 778-782. [CrossRef]

52. Buss, H.; Dörrie, A.; Schmitz, M.L.; Hoffmann, E.; Resch, K.; Kracht, M. Constitutive and interleukin-1-inducible phosphorylation of p65 NF- $\mathrm{kB}$ at serine 536 is mediated by multiple protein kinases including IKB kinase (IKK)- $\alpha$, IKK $\beta$, IKK $\varepsilon$, TRAF family member-associated (TANK)-binding kinase 1 (TBK1), and an unknown kinase and c. J. Biol. Chem. 2004, 279, 55633-55643. [CrossRef] [PubMed]

53. Liu, G.H.; Barkho, B.Z.; Ruiz, S.; Diep, D.; Qu, J.; Yang, S.L.; Panopoulos, A.D.; Suzuki, K.; Kurian, L.; Walsh, C.; et al. Recapitulation of premature ageing with iPSCs from Hutchinson-Gilford progeria syndrome. Nature 2011, 472, 221-225. [CrossRef]

54. Abe, T.; Barber, G.N. Cytosolic-DNA-Mediated, STING-Dependent Proinflammatory Gene Induction Necessitates Canonical NF-кB Activation through TBK1. J. Virol. 2014, 88, 5328-5341. [CrossRef] [PubMed]

55. Lam, A.R.; Bert, N.L.; Ho, S.S.W.; Shen, Y.J.; Tang, M.L.F.; Xiong, G.M.; Croxford, J.L.; Koo, C.X.; Ishii, K.J.; Akira, S.; et al. RAE1 ligands for the NKG2D receptor are regulated by STING-dependent DNA sensor pathways in lymphoma. Cancer Res. 2014, 74, 2193-2203. [CrossRef] [PubMed]

56. Hong, C.; Tijhuis, A.E.; Foijer, F. The cGAS Paradox: Contrasting Roles for cGAS-STING Pathway in Chromosomal Instability. Cells 2019, 8, 1228. [CrossRef] [PubMed] 
57. Bronner, C.E.; Baker, S.M.; Morrison, P.T.; Warren, G.; Smith, L.G.; Lescoe, M.K.; Kane, M.; Earabino, C.; Lipford, J.; Lindblom, A.; et al. Mutation in the DNA mismatch repair gene homologue hMLH1 is associated with hereditary non-polyposis colon cancer. Nature 1994, 368, 258-261. [CrossRef] [PubMed]

58. Yu, Q.; Katlinskaya, Y.V.; Carbone, C.J.; Zhao, B.; Katlinski, K.V.; Zheng, H.; Guha, M.; Li, N.; Chen, Q.; Yang, T.; et al. DNA-Damage-Induced Type I Interferon Promotes Senescence and Inhibits Stem Cell Function. Cell Rep. 2015, 11, 785-797. [CrossRef]

59. Shen, Y.J.; Le Bert, N.; Chitre, A.A.; Koo, C.X.; Nga, X.H.; Ho, S.S.W.; Khatoo, M.; Tan, N.Y.; Ishii, K.J.; Gasser, S. Genome-Derived Cytosolic DNA Mediates Type I Interferon-Dependent Rejection of B Cell Lymphoma Cells. Cell Rep. 2015, 11, 460-473. [CrossRef]

60. Coquel, F.; Silva, M.J.; Técher, H.; Zadorozhny, K.; Sharma, S.; Nieminuszczy, J.; Mettling, C.; Dardillac, E.; Barthe, A.; Schmitz, A.L.; et al. SAMHD1 acts at stalled replication forks to prevent interferon induction. Nature 2018, 557, 57-61. [CrossRef]

61. Luthra, P.; Aguirre, S.; Yen, B.C.; Pietzsch, C.A.; Sanchez-Aparicio, M.T.; Tigabu, B.; Morlock, L.K.; García-Sastre, A.; Leung, D.W.; Williams, N.S.; et al. Topoisomerase II inhibitors induce DNA damage-dependent interferon responses circumventing ebola virus immune evasion. MBio 2017, 8. [CrossRef]

62. Dunphy, G.; Flannery, S.M.; Almine, J.F.; Connolly, D.J.; Paulus, C.; Jønsson, K.L.; Jakobsen, M.R.; Nevels, M.M.; Bowie, A.G.; Unterholzner, L. Non-canonical Activation of the DNA Sensing Adaptor STING by ATM and IFI16 Mediates NF-кB Signaling after Nuclear DNA Damage. Mol. Cell 2018, 71, 745-760.e5. [CrossRef]

63. Coquel, F.; Neumayer, C.; Lin, Y.L.; Pasero, P. SAMHD1 and the innate immune response to cytosolic DNA during DNA replication. Curr. Opin. Immunol. 2019, 56, 24-30. [CrossRef]

64. Bhattacharya, S.; Srinivasan, K.; Abdisalaam, S.; Su, F.; Raj, P.; Dozmorov, I.; Mishra, R.; Wakeland, E.K.; Ghose, S.; Mukherjee, S.; et al. RAD51 interconnects between DNA replication, DNA repair and immunity. Nucleic Acids Res. 2017, 45, 4590-4605. [CrossRef] [PubMed]

65. Erdal, E.; Haider, S.; Rehwinkel, J.; Harris, A.L.; McHugh, P.J. A prosurvival DNA damage-induced cytoplasmic interferon response is mediated by end resection factors and is limited by Trex1. Genes Dev. 2017, 31, 353-369. [CrossRef] [PubMed]

66. Mankouri, H.W.; Huttner, D.; Hickson, I.D. How unfinished business from S-phase affects mitosis and beyond. EMBO J. 2013, 32, 2661-2671. [CrossRef] [PubMed]

67. Gelot, C.; Magdalou, I.; Lopez, B.S. Replication stress in mammalian cells and its consequences for mitosis. Genes 2015, 6. [CrossRef] [PubMed]

68. Wilhelm, T.; Magdalou, I.; Barascu, A.; Techer, H.; Debatisse, M.; Lopez, B.S. Spontaneous slow replication fork progression elicits mitosis alterations in homologous recombination-deficient mammalian cells. Proc. Natl. Acad. Sci. USA 2014, 111, 763-768. [CrossRef]

69. Harding, S.M.; Benci, J.L.; Irianto, J.; Discher, D.E.; Minn, A.J.; Greenberg, R.A. Mitotic progression following DNA damage enables pattern recognition within micronuclei. Nature 2017, 548, 466-470. [CrossRef]

70. Bartsch, K.; Knittler, K.; Borowski, C.; Rudnik, S.; Damme, M.; Aden, K.; Spehlmann, M.E.; Frey, N.; Saftig, P.; Chalaris, A.; et al. Absence of RNase $\mathrm{H} 2$ triggers generation of immunogenic micronuclei removed by autophagy. Hum. Mol. Genet. 2017, 26, 3960-3972. [CrossRef]

71. MacKenzie, K.J.; Carroll, P.; Martin, C.A.; Murina, O.; Fluteau, A.; Simpson, D.J.; Olova, N.; Sutcliffe, H.; Rainger, J.K.; Leitch, A.; et al. CGAS surveillance of micronuclei links genome instability to innate immunity. Nature 2017, 548, 461-465. [CrossRef]

72. Gekara, N.O. DNA damage-induced immune response: Micronuclei provide key platform. J. Cell Biol. 2017, 216, 2999-3001. [CrossRef] [PubMed]

73. Gratia, M.; Rodero, M.P.; Conrad, C.; Samra, E.B.; Maurin, M.; Rice, G.I.; Duffy, D.; Revy, P.; Petit, F.; Dale, R.C.; et al. Bloom syndrome protein restrains innate immune sensing of micronuclei by cGAS. J. Exp. Med. 2019, 216, 1199-1213. [CrossRef] [PubMed]

74. Reisländer, T.; Lombardi, E.P.; Groelly, F.J.; Miar, A.; Porru, M.; Di Vito, S.; Wright, B.; Lockstone, H.; Biroccio, A.; Harris, A.; et al. BRCA2 abrogation triggers innate immune responses potentiated by treatment with PARP inhibitors. Nat. Commun. 2019, 10. [CrossRef]

75. Atianand, M.K.; Fitzgerald, K.A. Molecular Basis of DNA Recognition in the Immune System. J. Immunol. 2013, 190, 1911-1918. [CrossRef] 
76. Wolf, C.; Rapp, A.; Berndt, N.; Staroske, W.; Schuster, M.; Dobrick-Mattheuer, M.; Kretschmer, S.; König, N.; Kurth, T.; Wieczorek, D.; et al. RPA and Rad51 constitute a cell intrinsic mechanism to protect the cytosol from self DNA. Nat. Commun. 2016, 7. [CrossRef] [PubMed]

77. Härtlova, A.; Erttmann, S.F.; Raffi, F.A.M.; Schmalz, A.M.; Resch, U.; Anugula, S.; Lienenklaus, S.; Nilsson, L.M.; Kröger, A.; Nilsson, J.A.; et al. DNA Damage Primes the Type I Interferon System via the Cytosolic DNA Sensor STING to Promote Anti-Microbial Innate Immunity. Immunity 2015, 42, 332-343. [CrossRef]

78. Saintigny, Y.; Delacôte, F.; Varès, G.; Petitot, F.; Lambert, S.; Averbeck, D.; Lopez, B.S. Characterization of homologous recombination induced by replication inhibition in mammalian cells. EMBO J. 2001, 20. [CrossRef]

79. So, A.; Le Guen, T.; Lopez, B.S.; Guirouilh-Barbat, J. Genomic rearrangements induced by unscheduled DNA double strand breaks in somatic mammalian cells. FEBS J. 2017, 284, 2324-2344. [CrossRef]

80. Berti, M.; Vindigni, A. Replication stress: Getting back on track. Nat. Struct. Mol. Biol. 2016, 23, $103-109$. [CrossRef]

81. Groth, A.; Corpet, A.; Cook, A.J.L.; Roche, D.; Bartek, J.; Lukas, J.; Almouzni, G. Regulation of replication fork progression through histone supply and demand. Science 2007, 318, 1928-1931. [CrossRef]

82. Saldivar, J.C.; Cortez, D.; Cimprich, K.A. The essential kinase ATR: Ensuring faithful duplication of a challenging genome. Nat. Rev. Mol. Cell Biol. 2017, 18, 622-636. [CrossRef]

83. Pasero, P.; Vindigni, A. Nucleases Acting at Stalled Forks: How to Reboot the Replication Program with a Few Shortcuts. Annu. Rev. Genet. 2017, 51, 477-499. [CrossRef]

84. Hanada, K.; Budzowska, M.; Davies, S.L.; van Drunen, E.; Onizawa, H.; Beverloo, H.B.; Maas, A.; Essers, J.; Hickson, I.D.; Kanaar, R. The structure-specific endonuclease Mus81 contributes to replication restart by generating double-strand DNA breaks. Nat. Struct Mol. Biol 2007, 14, 1096-1104. [CrossRef] [PubMed]

85. Maréchal, A.; Zou, L. DNA damage sensing by the ATM and ATR kinases. Cold Spring Harb. Perspect. Biol. 2013, 5. [CrossRef] [PubMed]

86. Blackford, A.N.; Jackson, S.P. ATM, ATR, and DNA-PK: The Trinity at the Heart of the DNA Damage Response. Mol. Cell 2017, 66, 801-817. [CrossRef] [PubMed]

87. Bétermier, M.; Bertrand, P.; Lopez, B.S. Is Non-Homologous End-Joining Really an Inherently Error-Prone Process? PLoS Genet. 2014, 10, e1004086. [CrossRef]

88. Guirouilh-Barbat, J.; Lambert, S.; Bertrand, P.; Lopez, B.S. Is homologous recombination really an error-free process? Front. Genet. 2014, 5, 175. [CrossRef]

89. Guirouilh-Barbat, J.; Huck, S.; Bertrand, P.; Pirzio, L.; Desmaze, C.; Sabatier, L.; Lopez, B.S. Impact of the KU80 pathway on NHEJ-induced genome rearrangements in mammalian cells. Mol. Cell 2004, 14, 611-623. [CrossRef]

90. Sallmyr, A.; Tomkinson, A.E. Repair of DNA double-strand breaks by mammalian alternative end-joining pathways. J. Biol. Chem. 2018, 293, 10536-10549. [CrossRef]

91. Rass, E.; Grabarz, A.; Plo, I.; Gautier, J.; Bertrand, P.; Lopez, B.S. Role of Mre11 in chromosomal nonhomologous end joining in mammalian cells. Nat. Struct. Mol. Biol. 2009, 16, 819-824. [CrossRef]

92. Dinkelmann, M.; Spehalski, E.; Stoneham, T.; Buis, J.; Wu, Y.; Sekiguchi, J.M.; Ferguson, D.O. Multiple functions of MRN in end-joining pathways during isotype class switching. Nat. Struct Mol. Biol 2009, 16, 808-813. [CrossRef]

93. Xie, A.; Kwok, A.; Scully, R. Role of mammalian Mre11 in classical and alternative nonhomologous end joining. Nat. Struct. Mol. Biol. 2009, 16, 814-818. [CrossRef]

94. Le Guen, T.; Ragu, S.; Guirouilh-Barbat, J.; Lopez, B.S. Role of the double-strand break repair pathway in the maintenance of genomic stability. Mol. Cell. Oncol. 2015, 2. [CrossRef]

95. Haber, J.E. Genome Stability: DNA Repair and Recombination; CRC Press: Boca Raton, FL, USA, 2013.

96. Lambert, S.; Lopez, B.S. Characterization of mammalian RAD51 double strand break repair using non lethal dominant negative forms. EMBO J. 2000, 19, 3090-3099. [CrossRef]

97. Schlacher, K.; Christ, N.; Siaud, N.; Egashira, A.; Wu, H.; Jasin, M. Double-strand break repair-independent role for BRCA2 in blocking stalled replication fork degradation by MRE11. Cell 2011, 145, 529-542. [CrossRef]

98. Ying, S.; Hamdy, F.C.; Helleday, T. Mre11-Dependent Degradation of Stalled DNA Replication Forks Is Prevented by BRCA2 and PARP1. Cancer Res. 2012, 72, 2814-2821. [CrossRef] 
99. Gelot, C.; Guirouilh-Barbat, J.; Lopez, B.S. The Cohesion complex maintains genome stability by preventing the end-joining of distant DNA ends in the S phase. Mol. Cell. Oncol. 2016, 5, e1154123. [CrossRef]

100. Rooney, S.; Chaudhuri, J.; Alt, F.W. The role of the non-homologous end-joining pathway in lymphocyte development. Immunol Rev. 2004, 200, 115-131. [CrossRef]

101. Stavnezer, J.; Guikema, J.E.J.; Schrader, C.E. Mechanism and Regulation of Class Switch Recombination. Annu. Rev. Immunol. 2008, 26, 261-292. [CrossRef]

102. Pavri, R. R loops in the regulation of antibody gene diversification. Genes 2017, 8, 154. [CrossRef]

103. Stavnezer, J.; Schrader, C.E. IgH Chain Class Switch Recombination: Mechanism and Regulation. J. Immunol. 2014, 193, 5370-5378. [CrossRef]

104. Xu, Z.; Zan, H.; Pone, E.J.; Mai, T.; Casali, P. Immunoglobulin class-switch DNA recombination: Induction, targeting and beyond. Nat. Rev. Immunol. 2012, 12, 517-531. [CrossRef]

105. Muramatsu, M.; Kinoshita, K.; Fagarasan, S.; Yamada, S.; Shinkai, Y.; Honjo, T. Class switch recombination and hypermutation require activation-induced cytidine deaminase (AID), a potential RNA editing enzyme. Cell 2000, 102, 553-563. [CrossRef]

106. Chaudhuri, J.; Tian, M.; Khuong, C.; Chua, K.; Pinaud, E.; Alt, F.W. Transcription-targeted DNA deamination by the AID antibody diversification enzyme. Nature 2003, 422, 726-730. [CrossRef]

107. Dickerson, S.K.; Market, E.; Besmer, E.; Papavasiliou, F.N. AID mediates hypermutation by deaminating single stranded DNA. J. Exp. Med. 2003, 197, 1291-1296. [CrossRef]

108. Pham, P.; Bransteitter, R.; Petruska, J.; Goodman, M.F. Processive AID-catalysed cytosine deamination on single-stranded DNA simulates somatic hypermutation. Nature 2003, 424, 103-107. [CrossRef]

109. Ramiro, A.R.; Stavropoulos, P.; Jankovic, M.; Nussenzweig, M.C. Transcription enhances AID-mediated cytidine deamination by exposing single-stranded DNA on the nontemplate strand. Nat. Immunol. 2003, 4, 452-456. [CrossRef]

110. Lavin, M.F. Ataxia-telangiectasia: From a rare disorder to a paradigm for cell signalling and cancer. Nat. Rev. Mol. Cell Biol. 2008, 9, 759-769. [CrossRef]

111. O'Driscoll, M.; Jeggo, P. Immunological disorders and DNA repair. Mutat. Res. Fundam. Mol. Mech. Mutagen. 2002, 509, 109-126. [CrossRef]

112. Figueiredo, N.; Chora, A.; Raquel, H.; Pejanovic, N.; Pereira, P.; Hartleben, B.; Neves-Costa, A.; Moita, C.; Pedroso, D.; Pinto, A.; et al. Anthracyclines induce DNA damage response-mediated protection against severe sepsis. Immunity 2013, 39, 874-884. [CrossRef]

113. Woodbine, L.; Gennery, A.R.; Jeggo, P.A. The clinical impact of deficiency in DNA non-homologous end-joining. DNA Repair 2014, 16, 84-96. [CrossRef] [PubMed]

114. Rivera-Munoz, P.; Malivert, L.; Derdouch, S.; Azerrad, C.; Abramowski, V.; Revy, P.; de Villartay, J.P. DNA repair and the immune system: From V(D)J recombination to aging lymphocytes. Eur. J. Immunol. 2007, 37. [CrossRef] [PubMed]

115. Ray Chaudhuri, A.; Nussenzweig, A. The multifaceted roles of PARP1 in DNA repair and chromatin remodelling. Nat. Rev. Mol. Cell Biol. 2017, 18, 610-621. [CrossRef] [PubMed]

116. Martin-Hernandez, K.; Rodriguez-Vargas, J.M.; Schreiber, V.; Dantzer, F. Expanding functions of ADP-ribosylation in the maintenance of genome integrity. Semin. Cell Dev. Biol. 2017, 63, 92-101. [CrossRef]

117. Ray Chaudhuri, A.; Hashimoto, Y.; Herrador, R.; Neelsen, K.J.; Fachinetti, D.; Bermejo, R.; Cocito, A.; Costanzo, V.; Lopes, M. Topoisomerase I poisoning results in PARP-mediated replication fork reversal. Nat. Struct. Mol. Biol. 2012, 19, 417-423. [CrossRef]

118. Bryant, H.E.; Petermann, E.; Schultz, N.; Jemth, A.S.; Loseva, O.; Issaeva, N.; Johansson, F.; Fernandez, S.; McGlynn, P.; Helleday, T. PARP is activated at stalled forks to mediate Mre11-dependent replication restart and recombination. EMBO J. 2009, 28, 2601-2615. [CrossRef]

119. Yang, Y.G.; Cortes, U.; Patnaik, S.; Jasin, M.; Wang, Z.Q. Ablation of PARP-1 does not interfere with the repair of DNA double-strand breaks, but compromises the reactivation of stalled replication forks. Oncogene 2004, 23, 3872-3882. [CrossRef]

120. Ronson, G.E.; Piberger, A.L.; Higgs, M.R.; Olsen, A.L.; Stewart, G.S.; McHugh, P.J.; Petermann, E.; Lakin, N.D. PARP1 and PARP2 stabilise replication forks at base excision repair intermediates through Fbh1-dependent Rad51 regulation. Nat. Commun. 2018, 9. [CrossRef] 
121. Hu, Y.; Petit, S.A.; Ficarro, S.B.; Toomire, K.J.; Xie, A.; Lim, E.; Cao, S.A.; Park, E.; Eck, M.J.; Scully, R.; et al. PARP1-driven poly-ADP-ribosylation regulates BRCA1 function in homologous recombination-mediated DNA repair. Cancer Discov. 2014, 4, 1430-1447. [CrossRef]

122. Hochegger, H.; Dejsuphong, D.; Fukushima, T.; Morrison, C.; Sonoda, E.; Schreiber, V.; Guang, Y.Z.; Saberi, A.; Masutani, M.; Adachi, N.; et al. Parp-1 protects homologous recombination from interference by Ku and Ligase IV in vertebrate cells. EMBO J. 2006, 25, 1305-1314. [CrossRef]

123. Luijsterburg, M.S.; de Krijger, I.; Wiegant, W.W.; Shah, R.G.; Smeenk, G.; de Groot, A.J.L.; Pines, A.; Vertegaal, A.C.O.; Jacobs, J.J.L.; Shah, G.M.; et al. PARP1 Links CHD2-Mediated Chromatin Expansion and H3.3 Deposition to DNA Repair by Non-homologous End-Joining. Mol. Cell 2016, 61, 547-562. [CrossRef] [PubMed]

124. Spagnolo, L.; Barbeau, J.; Curtin, N.J.; Morris, E.P.; Pearl, L.H. Visualization of a DNA-PK/PARP1 complex. Nucleic Acids Res. 2012, 40, 4168-4177. [CrossRef] [PubMed]

125. Robu, M.; Shah, R.G.; Petitclerc, N.; Brind'amour, J.; Kandan-Kulangara, F.; Shah, G.M. Role of poly(ADP-ribose) polymerase-1 in the removal of UV-induced DNA lesions by nucleotide excision repair. Proc. Natl. Acad. Sci. USA 2013, 110, 1658-1663. [CrossRef] [PubMed]

126. Pines, A.; Vrouwe, M.G.; Marteijn, J.A.; Typas, D.; Luijsterburg, M.S.; Cansoy, M.; Hensbergen, P.; Deelder, A.; de Groot, A.; Matsumoto, S.; et al. PARP1 promotes nucleotide excision repair through DDB2 stabilization and recruitment of ALC1. J. Cell Biol. 2012, 199, 235-249. [CrossRef]

127. Liu, Y.; Kadyrov, F.A.; Modrich, P. PARP-1 enhances the mismatch-dependence of 5'-directed excision in human mismatch repair in vitro. DNA Repair 2011, 10, 1145-1153. [CrossRef] [PubMed]

128. Dantzer, F.; De La Rubia, G.; Ménissier-De Murcia, J.; Hostomsky, Z.; De Murcia, G.; Schreiber, V. Base excision repair is impaired in mammalian cells lacking poly(ADP- ribose) polymerase-1. Biochemistry 2000, 39, 7559-7569. [CrossRef] [PubMed]

129. El-Khamisy, S.F.; Masutani, M.; Suzuki, H.; Caldecott, K.W. A requirement for PARP-1 for the assembly or stability of XRCC1 nuclear foci at sites of oxidative DNA damage. Nucleic Acids Res. 2003, 31, 5526-5533. [CrossRef]

130. Prasad, R.; Lavrik, O.I.; Kim, S.J.; Kedar, P.; Yang, X.P.; Vande Berg, B.J.; Wilson, S.H. DNA polymerase $\beta$-mediated long patch base excision repair: Poly(ADP-ribose) polymerase-1 stimulates strand displacement DNA synthesis. J. Biol. Chem. 2001, 276, 32411-32414. [CrossRef]

131. Hassa, P.O.; Covic, M.; Hasan, S.; Imhof, R.; Hottiger, M.O. The Enzymatic and DNA Binding Activity of PARP-1 Are Not Required for NF-кB Coactivator Function. J. Biol. Chem. 2001, 276, 45588-45597. [CrossRef]

132. Hassa, P.O.; Hottiger, M.O. The functional role of poly(ADP-ribose)polymerase 1 as novel coactivator of NF-kB in inflammatory disorders. Cell. Mol. Life Sci. 2002, 59, 1534-1553. [CrossRef]

133. Oliver, F.J.; Ménissier-de Murcia, J.; Nacci, C.; Decker, P.; Andriantsitohaina, R.; Muller, S.; De La Rubia, G.; Stoclet, J.C.; De Murcia, G. Resistance to endotoxic shock as a consequence of defective NF- $\mathrm{kB}$ activation in poly (ADP-ribose) polymerase-1 deficient mice. EMBO J. 1999, 18, 4446-4454. [CrossRef] [PubMed]

134. Mangerich, A.; Bürkle, A. Pleiotropic cellular functions of PARP1 in longevity and aging: Genome maintenance meets inflammation. Oxid. Med. Cell. Longev. 2012, 2012, 321653. [CrossRef] [PubMed]

135. Hassa, P.O.; Haenni, S.S.; Buerki, C.; Meier, N.I.; Lane, W.S.; Owen, H.; Gersbach, M.; Imhof, R.; Hottiger, M.O. Acetylation of poly(ADP-ribose) polymerase-1 by p300/CREB-binding protein regulates coactivation of NF-kB-dependent transcription. J. Biol. Chem. 2005, 280, 40450-40464. [CrossRef] [PubMed]

136. Dillon, M.T.; Bergerhoff, K.F.; Pedersen, M.; Whittock, H.; Crespo-Rodriguez, E.; Patin, E.C.; Pearson, A.; Smith, H.G.; Paget, J.T.E.; Patel, R.R.; et al. ATR inhibition potentiates the radiation-induced inflammatory tumor microenvironment. Clin. Cancer Res. 2019, 25, 3392-3403. [CrossRef] [PubMed]

137. Shiloh, Y. ATM and related protein kinases: Safeguarding genome integrity. Nat. Rev. Cancer 2003, 3, 155-168. [CrossRef] [PubMed]

138. Brégnard, C.; Guerra, J.; Déjardin, S.; Passalacqua, F.; Benkirane, M.; Laguette, N. Upregulated LINE-1 Activity in the Fanconi Anemia Cancer Susceptibility Syndrome Leads to Spontaneous Pro-inflammatory Cytokine Production. EBioMedicine 2016, 8, 184-194. [CrossRef] [PubMed]

139. Sugihara, T.; Murano, H.; Nakamura, M.; Ichinohe, K.; Tanaka, K. Activation of interferon-stimulated genes by g-Ray irradiation independently of the ataxia telangiectasia mutated-p53 pathway. Mol. Cancer Res. 2011, 9, 476-484. [CrossRef] 
140. Eickmeier, O.; Kim, S.Y.; Herrmann, E.; Döring, C.; Duecker, R.; Voss, S.; Wehner, S.; Hölscher, C.; Pietzner, J.; Zielen, S.; et al. Altered mucosal immune response after acute lung injury in a murine model of Ataxia Telangiectasia. BMC Pulm. Med. 2014, 14. [CrossRef]

141. Paull, T.T. 20 Years of Mre11 Biology: No End in Sight. Mol. Cell 2018, 71, 419-427. [CrossRef]

142. Myler, L.R.; Gallardo, I.F.; Soniat, M.M.; Deshpande, R.A.; Gonzalez, X.B.; Kim, Y.; Paull, T.T.; Finkelstein, I.J. Single-Molecule Imaging Reveals How Mre11-Rad50-Nbs1 Initiates DNA Break Repair. Mol. Cell 2017, 67, 891-898.e4. [CrossRef]

143. Takeda, S.; Nakamura, K.; Taniguchi, Y.; Paull, T.T. Ctp1/CtIP and the MRN Complex Collaborate in the Initial Steps of Homologous Recombination. Mol. Cell 2007, 28, 351-352. [CrossRef] [PubMed]

144. Paull, T.T. Making the best of the loose ends: Mre11/Rad50 complexes and Sae2 promote DNA double-strand break resection. DNA Repair 2010, 9, 1283-1291. [CrossRef]

145. Lamarche, B.J.; Orazio, N.I.; Weitzman, M.D. The MRN complex in double-strand break repair and telomere maintenance. FEBS Lett. 2010, 584, 3682-3695. [CrossRef] [PubMed]

146. Paull, T.T.; Deshpande, R.A. The Mre11/Rad50/Nbs1 complex: Recent insights into catalytic activities and ATP-driven conformational changes. Exp. Cell Res. 2014, 329, 139-147. [CrossRef] [PubMed]

147. Pereira-Lopes, S.; Tur, J.; Calatayud-Subias, J.A.; Lloberas, J.; Stracker, T.H.; Celada, A. NBS1 is required for macrophage homeostasis and functional activity in mice. Blood 2015, 126, 2502-2510. [CrossRef]

148. Prochazkova, J.; Sakaguchi, S.; Owusu, M.; Mazouzi, A.; Wiedner, M.; Velimezi, G.; Moder, M.; Turchinovich, G.; Hladik, A.; Gurnhofer, E.; et al. DNA Repair Cofactors ATMIN and NBS1 Are Required to Suppress T Cell Activation. PLoS Genet. 2015, 11. [CrossRef]

149. Seidel, P.; Remus, M.; Delacher, M.; Grigaravicius, P.; Reuss, D.E.; Frappart, L.; von Deimling, A.; Feueuer, M.; Abdollahi, A.; Frappart, P.O. Epidermal Nbn deletion causes premature hair loss and a phenotype resembling psoriasiform dermatitis. Oncotarget 2016, 7, 23006-23018. [CrossRef]

150. Roth, S.; Rottach, A.; Lotz-Havla, A.S.; Laux, V.; Muschaweckh, A.; Gersting, S.W.; Muntau, A.C.; Hopfner, K.P.; Jin, L.; Vanness, K.; et al. Rad50-CARD9 interactions link cytosolic DNA sensing to IL-1 $\beta$ production. Nat. Immunol. 2014, 15, 538-545. [CrossRef]

151. Kondo, T.; Kobayashi, J.; Saitoh, T.; Maruyama, K.; Ishii, K.J.; Barber, G.N.; Komatsu, K.; Akira, S.; Kawai, T. DNA damage sensor MRE11 recognizes cytosolic double-stranded DNA and induces type i interferon by regulating STING trafficking. Proc. Natl. Acad. Sci. USA 2013, 110, 2969-2974. [CrossRef]

152. Rice, G.I.; Rodero, M.P.; Crow, Y.J. Human Disease Phenotypes Associated With Mutations in TREX1. J. Clin. Immunol. 2015, 35, 235-243. [CrossRef]

153. Crow, Y.J.; Rehwinkel, J. Aicardi-Goutie'res syndrome and related phenotypes: Linking nucleic acid metabolism with autoimmunity. Hum. Mol. Genet. 2009, 18. [CrossRef] [PubMed]

154. Orcesi, S.; La Piana, R.; Fazzi, E. Aicardi-Goutires syndrome. Br. Med. Bull. 2009, 89, 183-201. [CrossRef] [PubMed]

155. Chahwan, C.; Chahwan, R. Aicardi-Goutieres syndrome: From patients to genes and beyond. Clin. Genet. 2012, 81, 413-420. [CrossRef] [PubMed]

156. Gall, A.; Treuting, P.; Elkon, K.B.; Loo, Y.M.; Gale, M.; Barber, G.N.; Stetson, D.B. Autoimmunity Initiates in Nonhematopoietic Cells and Progresses via Lymphocytes in an Interferon-Dependent Autoimmune Disease. Immunity 2012, 36, 120-131. [CrossRef]

157. Ahn, J.; Barber, G.N. Self-DNA, STING-dependent signaling and the origins of autoinflammatory disease. Curr. Opin. Immunol. 2014, 31, 121-126. [CrossRef]

158. Gray, E.E.; Treuting, P.M.; Woodward, J.J.; Stetson, D.B. Cutting Edge: cGAS Is Required for Lethal Autoimmune Disease in the Trex1-Deficient Mouse Model of Aicardi-Goutières Syndrome. J. Immunol. 2015, 195, 1939-1943. [CrossRef]

159. Gao, D.; Li, T.; Li, X.D.; Chen, X.; Li, Q.Z.; Wight-Carter, M.; Chen, Z.J. Activation of cyclic GMP-AMP synthase by self-DNA causes autoimmune diseases. Proc. Natl. Acad. Sci. USA 2015, 112, E5699-E5705. [CrossRef]

160. Crow, Y.J.; Hayward, B.E.; Parmar, R.; Robins, P.; Leitch, A.; Ali, M.; Black, D.N.; Van Bokhoven, H.; Brunner, H.G.; Hamel, B.C.; et al. Mutations in the gene encoding the $3^{\prime}-5^{\prime}$ DNA exonuclease TREX1 cause Aicardi-Goutières syndrome at the AGS1 locus. Nat. Genet. 2006, 38, 917-920. [CrossRef] 
161. Pokatayev, V.; Hasin, N.; Chon, H.; Cerritelli, S.M.; Sakhuja, K.; Ward, J.M.; Douglas Morris, H.; Yan, N.; Crouch, R.J. RNase H2 catalytic core Aicardi-Goutières syndrome-Related mutant invokes cGAS-STING innate immunesensing pathway in mice. J. Exp. Med. 2016, 213, 329-336. [CrossRef]

162. Daddacha, W.; Koyen, A.E.; Bastien, A.J.; Head, P.S.E.; Dhere, V.R.; Nabeta, G.N.; Connolly, E.C.; Werner, E.; Madden, M.Z.; Daly, M.B.; et al. SAMHD1 Promotes DNA End Resection to Facilitate DNA Repair by Homologous Recombination. Cell Rep. 2017, 20, 1921-1935. [CrossRef]

163. Fackenthal, J.D.; Olopade, O.I. Breast cancer risk associated with BRCA1 and BRCA2 in diverse populations. Nat. Rev. Cancer 2007, 7, 937-948. [CrossRef] [PubMed]

164. Alsop, K.; Fereday, S.; Meldrum, C.; DeFazio, A.; Emmanuel, C.; George, J.; Dobrovic, A.; Birrer, M.J.; Webb, P.M.; Stewart, C.; et al. BRCA mutation frequency and patterns of treatment response in BRCA mutation-positive women with ovarian cancer: A report from the Australian ovarian cancer study group. J. Clin. Oncol. 2012, 30, 2654-2663. [CrossRef] [PubMed]

165. Daboussi, F.; Courbet, S.; Benhamou, S.; Kannouche, P.; Zdzienicka, M.Z.; Debatisse, M.; Lopez, B.S. A homologous recombination defect affects replication-fork progression in mammalian cells. J. Cell Sci. 2008, 121, 162-166. [CrossRef] [PubMed]

166. Heijink, A.M.; Talens, F.; Jae, L.T.; van Gijn, S.E.; Fehrmann, R.S.N.; Brummelkamp, T.R.; van Vugt, M.A.T.M. BRCA2 deficiency instigates cGAS-mediated inflammatory signaling and confers sensitivity to tumor necrosis factor-alpha-mediated cytotoxicity. Nat. Commun. 2019, 10. [CrossRef] [PubMed]

167. Parkes, E.E.; Walker, S.M.; Taggart, L.E.; McCabe, N.; Knight, L.A.; Wilkinson, R.; McCloskey, K.D.; Buckley, N.E.; Savage, K.I.; Salto-Tellez, M.; et al. Activation of STING-dependent innate immune signaling by s-phase-specific DNA damage in breast cancer. J. Natl. Cancer Inst. 2017, 109. [CrossRef]

168. Dutta, D.; Dutta, S.; Veettil, M.V.; Roy, A.; Ansari, M.A.; Iqbal, J.; Chikoti, L.; Kumar, B.; Johnson, K.E.; Chandran, B. BRCA1 Regulates IFI16 Mediated Nuclear Innate Sensing of Herpes Viral DNA and Subsequent Induction of the Innate Inflammasome and Interferon- $\beta$ Responses. PLoS Pathog. 2015, 11. [CrossRef]

169. Gangloff, S.; Soustelle, C.; Fabre, F. Homologous recombination is responsible for cell death in the absence of the Sgs1 and Srs2 helicases. Nat. Genet. 2000, 25, 192-194. [CrossRef]

170. Ciccia, A.; McDonald, N.; West, S.C. Structural and Functional Relationships of the XPF/MUS81 Family of Proteins. Annu. Rev. Biochem. 2008, 77, 259-287. [CrossRef]

171. Ho, S.S.W.; Zhang, W.Y.L.; Tan, N.Y.J.; Khatoo, M.; Suter, M.A.; Tripathi, S.; Cheung, F.S.G.; Lim, W.K.; Tan, P.H.; Ngeow, J.; et al. The DNA Structure-Specific Endonuclease MUS81 Mediates DNA Sensor STING-Dependent Host Rejection of Prostate Cancer Cells. Immunity 2016, 44, 1177-1189. [CrossRef]

172. Dufour, C.; Corcione, A.; Svahn, J.; Haupt, R.; Poggi, V.; Béka'ssy, A.N.; Scimè, R.; Pistorio, A.; Pistoia, V. TNF- $\alpha$ and IFN- $\gamma$ are overexpressed in the bone marrow of Fanconi anemia patients and TNF- $\alpha$ suppresses erythropoiesis in vitro. Blood 2003, 102, 2053-2059. [CrossRef]

173. Sumpter, R.; Sirasanagandla, S.; Fernández, Á.F.; Wei, Y.; Dong, X.; Franco, L.; Zou, Z.; Marchal, C.; Lee, M.Y.; Clapp, D.W.; et al. Fanconi Anemia Proteins Function in Mitophagy and Immunity. Cell 2016, 165, 867-881. [CrossRef] [PubMed]

174. Cunniff, C.; Bassetti, J.A.; Ellis, N.A. Bloom's syndrome: Clinical spectrum, molecular pathogenesis, and cancer predisposition. Mol. Syndromol. 2017, 8, 4-23. [CrossRef] [PubMed]

175. Gravel, S.; Chapman, J.R.; Magill, C.; Jackson, S.P. DNA helicases Sgs1 and BLM promote DNA double-strand break resection. Genes Dev. 2008, 22, 2767-2772. [CrossRef] [PubMed]

176. Nimonkar, A.V.; Genschel, J.; Kinoshita, E.; Polaczek, P.; Campbell, J.L.; Wyman, C.; Modrich, P.; Kowalczykowski, S.C. BLM-DNA2-RPA-MRN and EXO1-BLM-RPA-MRN constitute two DNA end resection machineries for human DNA break repair. Genes Dev. 2011, 25, 350-362. [CrossRef] [PubMed]

177. Grabarz, A.; Guirouilh-Barbat, J.J.; Barascu, A.A.; Pennarun, G.G.; Genet, D.; Rass, E.; Germann, S.M.; Bertrand, P.; Hickson, I.D.; Lopez, B.S. A role for BLM in double-strand break repair pathway choice: Prevention of CtIP/Mre11-mediated alternative nonhomologous end-joining. Cell Rep. 2013, 5, 21-28. [CrossRef] [PubMed]

178. Goto, M.; Miller, R.W.; Ishikawa, Y.; Sugano, H. Excess of rare cancers in Werner syndrome (adult progeria). Cancer Epidemiol. Biomarkers Prev. 1996, 5, 239-246.

179. Goto, M. Hierarchical deterioration of body systems in Werner's syndrome: Implications for normal ageing. Mech. Ageing Dev. 1997, 98, 239-254. [CrossRef]

180. Goto, M. Werner's syndrome: From clinics to genetics. Clin. Exp. Rheumatol. 2000, 18, 760-766. [PubMed] 
181. Turaga, R.V.N.; Paquet, E.R.; Sild, M.; Vignard, J.; Garand, C.; Johnson, F.B.; Masson, J.Y.; Lebel, M. The Werner syndrome protein affects the expression of genes involved in adipogenesis and inflammation in addition to cell cycle and DNA damage responses. Cell Cycle 2009, 8, 2080-2092. [CrossRef]

182. Lebel, M.; Massip, L.; Garand, C.; Thorin, E. Ascorbate improves metabolic abnormalities in Wrn mutant mice but not the free radical scavenger catechin. Ann. N Y Acad. Sci. 2010, 1197, 40-44.

183. Goto, M.; Sugimoto, K.; Hayashi, S.; Ogino, T.; Sugimoto, M.; Furuichi, Y.; Matsuura, M.; Ishikawa, Y.; Iwaki-Egawa, S.; Watanabe, Y. Aging-associated inflammation in healthy Japanese individuals and patients with Werner syndrome. Exp. Gerontol. 2012, 47, 936-939. [CrossRef]

184. Van der Burg, M.; IJspeert, H.; Verkaik, N.; Turul, T.; Wiegant, W.; Morotomi-Yano, K.; Mari, P.-O.; Tezcan, I.; Chen, D.; Zdzienicka, M.; et al. A DNA-PKcs mutation in a radiosensitive T-B-SCID patient inhibits Artemis activation and nonhomologous end-joining. J. Clin. Invest. 2008, 119, 91-98. [CrossRef] [PubMed]

185. Hwang, J.K.; Alt, F.W.; Yeap, L.-S. Related Mechanisms of Antibody Somatic Hypermutation and Class Switch Recombination. Microbiol. Spectr. 2015, 3. [CrossRef] [PubMed]

186. Ferguson, B.J.; Mansur, D.S.; Peters, N.E.; Ren, H.; Smith, G.L. DNA-PK is a DNA sensor for IRF-3-dependent innate immunity. Elife 2012, 2012. [CrossRef] [PubMed]

187. Monroe, K.M.; Yang, Z.; Johnson, J.R.; Geng, X.; Doitsh, G.; Krogan, N.J.; Greene, W.C. IFI16 DNA sensor is required for death of lymphoid CD4 T cells abortively infected with HIV. Science 2014, 343, 428-432. [CrossRef]

188. Zhang, X.; Brann, T.W.; Zhou, M.; Yang, J.; Oguariri, R.M.; Lidie, K.B.; Imamichi, H.; Huang, D.-W.; Lempicki, R.A.; Baseler, M.W.; et al. Cutting Edge: Ku70 Is a Novel Cytosolic DNA Sensor That Induces Type III Rather Than Type I IFN. J. Immunol. 2011, 186, 4541-4545. [CrossRef]

189. Nakad, R.; Schumacher, B. DNA damage response and immune defense: Links and mechanisms. Front. Genet. 2016, 7. [CrossRef]

190. Diderich, K.; Alanazi, M.; Hoeijmakers, J.H.J. Premature aging and cancer in nucleotide excision repair-disorders. DNA Repair 2011, 10, 772-780. [CrossRef]

191. Nouspikel, T. DNA repair in mammalian cells: Nucleotide excision repair: Variations on versatility. Cell. Mol. Life Sci. 2009, 66, 994-1009. [CrossRef]

192. De Boer, J.; Hoeijmakers, J.H.J. Nucleotide excision repair and human syndromes. Carcinogenesis 2000, 21, 453-460. [CrossRef]

193. David, S.S.; Williams, S.D. Chemistry of glycosylases and endonucleases involved in base-excision repair. Chem. Rev. 1998, 98, 1221-1261. [CrossRef]

194. Huffman, J.L.; Sundheim, O.; Tainer, J.A. DNA base damage recognition and removal: New twists and grooves. Mutat. Res. Fundam. Mol. Mech. Mutagen. 2005, 577, 55-76. [CrossRef]

195. Dalhus, B.; Laerdahl, J.K.; Backe, P.H.; Bjørås, M. DNA base repair-Recognition and initiation of catalysis. FEMS Microbiol. Rev. 2009, 33, 1044-1078. [CrossRef] [PubMed]

196. Hang, B. Base excision repair. In DNA Repair, Genetic Instability, and Cancer; World Scientific: Singapore, 2007; pp. 23-64. ISBN 9789812706782.

197. Fromme, J.C.; Verdine, G.L. Base excision repair. Adv. Protein Chem. 2004, 69, 1-41. [PubMed]

198. Peña-Diaz, J.; Jiricny, J. Mammalian mismatch repair: Error-free or error-prone? Trends Biochem. Sci. 2012, 37, 206-214. [CrossRef] [PubMed]

199. Jiricny, J. Postreplicative mismatch repair. Cold Spring Harb. Perspect. Biol. 2013, 5, 1-23. [CrossRef] [PubMed]

200. Karakasilioti, I.; Kamileri, I.; Chatzinikolaou, G.; Kosteas, T.; Vergadi, E.; Robinson, A.R.; Tsamardinos, I.; Rozgaja, T.A.; Siakouli, S.; Tsatsanis, C.; et al. DNA damage triggers a chronic autoinflammatory response, leading to fat depletion in NER progeria. Cell Metab. 2013, 18, 403-415. [CrossRef]

201. Tilstra, J.S.; Robinson, A.R.; Wang, J.; Gregg, S.Q.; Clauson, C.L.; Reay, D.P.; Nasto, L.A.; St Croix, C.M.; Usas, A.; Vo, N.; et al. NF-kB inhibition delays DNA damage-Induced senescence and aging in mice. J. Clin. Invest. 2012, 122, 2601-2612. [CrossRef] [PubMed]

202. Da Silva, T.A.; Fontes, F.L.; Coutinho, L.G.; de Souza, F.R.S.; de Melo, J.T.A.; de Souto, J.T.; Leib, S.L.; Agnez-Lima, L.F. SNPs in DNA repair genes associated to meningitis and host immune response. Mutat. Res. Fundam. Mol. Mech. Mutagen. 2011, 713, 39-47. [CrossRef]

203. Touati, E.; Michel, V.; Thiberge, J.M.; Avé, P.; Huerre, M.; Bourgade, F.; Klungland, A.; Labigne, A. Deficiency in OGG1 protects against inflammation and mutagenic effects associated with $\mathrm{H}$. pylori infection in mouse. Helicobacter 2006, 11, 494-505. [CrossRef] 
204. Guikema, J.E.J.; Linehan, E.K.; Esa, N.; Tsuchimoto, D.; Nakabeppu, Y.; Woodland, R.T.; Schrader, C.E. AP endonuclease 2 regulates the expansion of germinal centers by protecting against AID-independent DNA damage in B cells 1. J. Immunol. 2014, 15, 931-939. [CrossRef]

205. Fung, H.; Demple, B. A vital role for Ape1/Ref1 protein in repairing spontaneous DNA damage in human cells. Mol. Cell 2005, 17, 463-470. [CrossRef] [PubMed]

206. Germano, G.; Lamba, S.; Rospo, G.; Barault, L.; Magri, A.; Maione, F.; Russo, M.; Crisafulli, G.; Bartolini, A.; Lerda, G.; et al. Inactivation of DNA repair triggers neoantigen generation and impairs tumour growth. Nature 2017, 552, 1-5. [CrossRef]

207. Drost, J.; van Boxtel, R.; Blokzijl, F.; Mizutani, T.; Sasaki, N.; Sasselli, V.; de Ligt, J.; Behjati, S.; Grolleman, J.E.; van Wezel, T.; et al. Use of CRISPR-modified human stem cell organoids to study the origin of mutational signatures in cancer. Science 2017, 358, 234-238. [CrossRef]

208. Cavazzana, I.; Ceribelli, A.; Quinzanini, M.; Scarsi, M.; Airò, P.; Cattaneo, R.; Franceschini, F. Prevalence and clinical associations of anti-Ku antibodies in systemic autoimmune diseases. Lupus 2008, 17, 727-732. [CrossRef] [PubMed]

209. Schild-Poulter, C.; Su, A.; Shih, A.; Kelly, O.P.; Fritzler, M.J.; Goldstein, R.; Haché, R.J.G. Association of autoantibodies with $\mathrm{Ku}$ and DNA repair proteins in connective tissue diseases. Rheumatology 2008, 47, 165-171. [CrossRef] [PubMed]

210. Davies, R.C.; Pettijohn, K.; Fike, F.; Wang, J.; Nahas, S.A.; Tunuguntla, R.; Hu, H.; Gatti, R.A.; McCurdy, D. Defective DNA double-strand break repair in pediatric systemic lupus erythematosus. Arthritis Rheum. 2012, 64, 568-578. [CrossRef] [PubMed]

211. Bawadekar, M.; De Andrea, M.; Lo Cigno, I.; Baldanzi, G.; Caneparo, V.; Graziani, A.; Landolfo, S.; Gariglio, M. The Extracellular IFI16 Protein Propagates Inflammation in Endothelial Cells Via p38 MAPK and NF-кB p65 Activation. J. Interf. Cytokine Res. 2015, 35, 441-453. [CrossRef]

212. Commoner, B.; Townsend, J.; Pake, G.E. Free radicals in biological materials. Nature 1954, 174, 689-691. [CrossRef]

213. Wallace, S.S. Biological consequences of free radical-damaged DNA bases. Free Radic. Biol. Med. 2002, 33, 1-14. [CrossRef]

214. Kawanishi, S.; Hiraku, Y. Oxidative and nitrative DNA damage as biomarker for carcinogenesis with special reference to inflammation. Antioxid. Redox Signal. 2006, 8, 1047-1058. [CrossRef]

215. Murata, M.; Thanan, R.; Ma, N.; Kawanishi, S. Role of nitrative and oxidative DNA damage in inflammation-related carcinogenesis. J. Biomed. Biotechnol. 2012, 2012. [CrossRef] [PubMed]

216. Kawanishi, S.; Ohnishi, S.; Ma, N.; Hiraku, Y.; Oikawa, S.; Murata, M. Nitrative and oxidative DNA damage in infection-related carcinogenesis in relation to cancer stem cells. Genes Environ. 2017, 39. [CrossRef] [PubMed]

217. Ameziane-El-Hassani, R.; Schlumberger, M.; Dupuy, C. NADPH oxidases: New actors in thyroid cancer? Nat. Rev. Endocrinol. 2016, 12, 485-494. [CrossRef] [PubMed]

218. Dahlgren, C.; Karlsson, A. Respiratory burst in human neutrophils. J. Immunol. Methods 1999, 232 , 3-14. [CrossRef]

219. Zhang, J.; Wang, X.; Vikash, V.; Ye, Q.; Wu, D.; Liu, Y.; Dong, W. ROS and ROS-Mediated Cellular Signaling. Oxid. Med. Cell. Longev. 2016, 2016. [CrossRef]

220. Perry, J.J.P.; Shin, D.S.; Getzoff, E.D.; Tainer, J.A. The structural biochemistry of the superoxide dismutases. Biochim. Biophys. Acta Proteins Proteomics 2010, 1804, 245-262. [CrossRef]

221. Meitzler, J.L.; Antony, S.; Wu, Y.; Juhasz, A.; Liu, H.; Jiang, G.; Lu, J.; Roy, K.; Doroshow, J.H. NADPH oxidases: A perspective on reactive oxygen species production in tumor biology. Antioxid. Redox Signal. 2014, 20, 2873-2889. [CrossRef]

222. Fransen, M.; Nordgren, M.; Wang, B.; Apanasets, O. Role of peroxisomes in ROS/RNS-metabolism: Implications for human disease. Biochim. Biophys. Acta Mol. Basis Dis. 2012, 1822, 1363-1373. [CrossRef]

223. Ziech, D.; Franco, R.; Pappa, A.; Panayiotidis, M.I. Reactive oxygen species (ROS)-induced genetic and epigenetic alterations in human carcinogenesis. Mutat. Res. 2011, 711, 167-173. [CrossRef]

224. Won, J.K.; Bakhoum, S.F. The cytosolic DNA-sensing cGAS-sting pathway in cancer. Cancer Discov. 2020, 10, 26-39. 
225. Gehrke, N.; Mertens, C.; Zillinger, T.; Wenzel, J.; Bald, T.; Zahn, S.; Tüting, T.; Hartmann, G.; Barchet, W. Oxidative damage of dna confers resistance to cytosolic nuclease trex 1 degradation and potentiates STING-dependent immune sensing. Immunity 2013, 39, 482-495. [CrossRef] [PubMed]

226. Chen, Y.; Zhou, Z.; Min, W. Mitochondria, oxidative stress and innate immunity. Front. Physiol. $2018,9$. [CrossRef] [PubMed]

227. Mittal, M.; Siddiqui, M.R.; Tran, K.; Reddy, S.P.; Malik, A.B. Reactive oxygen species in inflammation and tissue injury. Antioxid. Redox Signal. 2014, 20, 1126-1167. [CrossRef] [PubMed]

228. Hussain, S.P.; Hofseth, L.J.; Harris, C.C. Radical causes of cancer. Nat. Rev. Cancer 2003, 3, 276-285. [CrossRef] [PubMed]

229. Wiseman, H.; Halliwell, B. Damage to DNA by reactive oxygen and nitrogen species: Role in inflammatory disease and progression to cancer. Biochem. J. 1996, 313, 17-29. [CrossRef]

230. Fukumura, D.; Kashiwagi, S.; Jain, R.K. The role of nitric oxide in tumour progression. Nat. Rev. Cancer 2006, 6, 521-534. [CrossRef] [PubMed]

231. Lala, P.K.; Chakraborty, C. Role of nitric oxide in carcinogenesis and tumour progression. Lancet Oncol. 2001, 2, 149-156. [CrossRef]

232. Riaz, N.; Morris, L.; Havel, J.J.; Makarov, V.; Desrichard, A.; Chan, T.A. The role of neoantigens in response to immune checkpoint blockade. Int. Immunol. 2016, 28, 411-419. [CrossRef]

233. Ma, J.; Setton, J.; Lee, N.Y.; Riaz, N.; Powell, S.N. The therapeutic significance of mutational signatures from DNA repair deficiency in cancer. Nat. Commun. 2018, 9. [CrossRef]

234. Sistigu, A.; Yamazaki, T.; Vacchelli, E.; Chaba, K.; Enot, D.P.; Adam, J.; Vitale, I.; Goubar, A.; Baracco, E.E.; Remédios, C.; et al. Cancer cell-autonomous contribution of type I interferon signaling to the efficacy of chemotherapy. Nat. Med. 2014, 20, 1301-1309. [CrossRef]

235. Burnette, B.C.; Liang, H.; Lee, Y.; Chlewicki, L.; Khodarev, N.N.; Weichselbaum, R.R.; Fu, Y.X.; Auh, S.L. The efficacy of radiotherapy relies upon induction of type I interferon-dependent innate and adaptive immunity. Cancer Res. 2011, 71, 2488-2496. [CrossRef] [PubMed]

236. Lim, J.; Gerber, S.; Lord, E. The role of Type I interferons in antitumor responses: Implications in radiation therapy. J. Immunol. 2011, 186.

237. Deng, L.; Liang, H.; Xu, M.; Yang, X.; Burnette, B.; Arina, A.; Li, X.D.; Mauceri, H.; Beckett, M.; Darga, T.; et al. STING-dependent cytosolic DNA sensing promotes radiation-induced type I interferon-dependent antitumor immunity in immunogenic tumors. Immunity 2014, 41, 843-852. [CrossRef] [PubMed]

238. He, L.; Xiao, X.; Yang, X.; Zhang, Z.; Wu, L.; Liu, Z. STING signaling in tumorigenesis and cancer therapy: A friend or foe? Cancer Lett. 2017, 402, 203-212. [CrossRef]

239. Xia, T.; Konno, H.; Ahn, J.; Barber, G.N. Deregulation of STING Signaling in Colorectal Carcinoma Constrains DNA Damage Responses and Correlates With Tumorigenesis. Cell Rep. 2016, 14, 282-297. [CrossRef]

240. Ahn, J.; Xia, T.; Konno, H.; Konno, K.; Ruiz, P.; Barber, G.N. Inflammation-driven carcinogenesis is mediated through STING. Nat. Commun. 2014, 5. [CrossRef] [PubMed]

241. Zhu, Q.; Man, S.M.; Gurung, P.; Liu, Z.; Vogel, P.; Lamkanfi, M.; Kanneganti, T.-D. Cutting Edge: STING Mediates Protection against Colorectal Tumorigenesis by Governing the Magnitude of Intestinal Inflammation. J. Immunol. 2014, 193, 4779-4782. [CrossRef] [PubMed]

242. Gaston, J.; Cheradame, L.; Yvonnet, V.; Deas, O.; Poupon, M.F.; Judde, J.G.; Cairo, S.; Goffin, V. Intracellular STING inactivation sensitizes breast cancer cells to genotoxic agents. Oncotarget 2016, 7, 77205-77224. [CrossRef] [PubMed]

243. Strickland, K.C.; Howitt, B.E.; Shukla, S.A.; Rodig, S.; Ritterhouse, L.L.; Liu, J.F.; Garber, J.E.; Chowdhury, D.; $\mathrm{Wu}$, C.J.; D'Andrea, A.D.; et al. Association and prognostic significance of BRCA1/2-mutation status with neoantigen load, number of tumor-infiltrating lymphocytes and expression of PD-1/PD-L1 in high grade serous ovarian cancer. Oncotarget 2016, 7, 13587-13598. [CrossRef]

244. Schoonen, P.M.; Kok, Y.P.; Wierenga, E.; Bakker, B.; Foijer, F.; Spierings, D.C.J.; van Vugt, M.A.T.M. Premature mitotic entry induced by ATR inhibition potentiates olaparib inhibition-mediated genomic instability, inflammatory signaling, and cytotoxicity in BRCA2-deficient cancer cells. Mol. Oncol. 2019, 13, 2422-2440. [CrossRef]

245. Sen, T.; Rodriguez, B.L.; Chen, L.; Della Corte, C.M.; Morikawa, N.; Fujimoto, J.; Cristea, S.; Nguyen, T.; Diao, L.; Li, L.; et al. Targeting DNA damage response promotes antitumor immunity through STING-mediated T-cell activation in small cell lung cancer. Cancer Discov. 2019, 9, 646-661. [CrossRef] [PubMed] 
246. Chabanon, R.M.; Muirhead, G.; Krastev, D.B.; Adam, J.; Morel, D.; Garrido, M.; Lamb, A.; Hénon, C.; Dorvault, N.; Rouanne, M.; et al. PARP inhibition enhances tumor cell-intrinsic immunity in ERCC1-deficient non-small cell lung cancer. J. Clin. Invest. 2019, 129, 1211-1228. [CrossRef]

247. Ubhi, T.; Brown, G.W. Exploiting DNA replication stress for cancer treatment. Cancer Res. 2019, 79, 1730-1739. [CrossRef] [PubMed]

248. Lecona, E.; Fernandez-Capetillo, O. Targeting ATR in cancer. Nat. Rev. Cancer 2018, 18, 586-595. [CrossRef] [PubMed]

(C) 2020 by the authors. Licensee MDPI, Basel, Switzerland. This article is an open access article distributed under the terms and conditions of the Creative Commons Attribution (CC BY) license (http://creativecommons.org/licenses/by/4.0/). 